\title{
The Participation of Colombia in United Nations' Multidimensional Peace Operations
}

\author{
A Complex National Dilemma
}

\section{Andres Eduardo Fernandez-Osorio}

Escuela Militar de Cadetes General Jose Maria Cordova, Calle 8o No. 38-oo, Bogota D.C., Colombia

andres.fernandez@esmic.edu.co

\begin{abstract}
This article challenges conventional explanations why Colombia, a country emerging from an armed internal conflict but still with multiple challenges, should participate in United Nations' multidimensional peace operations. While Colombian official rationale maintains that contribution to peacekeeping is a common stage for countries

* The research for this article was supported by the Colombian Military Academy (Escuela Militar de Cadetes General Jose Maria Cordova - ESMIC) [grant numbers 542-ESMICBASPC19-2015 and 129-ESMIC-BASPC19-2016] and developed by its research group on Military Sciences under the code COL0082556 of Colciencias. No financial interest or benefit has arisen from the direct applications of this research. The views expressed on this paper are those of the author and do not necessarily represent the official positions of the Colombian government, the Ministry of Defense or the National Army of Colombia.

** Andres Eduardo Fernandez-Osorio, oRCID ID: 00oo-0003-0643-0258, is a Lieutenant Colonel in the National Army of Colombia currently serving as an associate professor at the Colombian Military Academy (Escuela Militar de Cadetes General Jose Maria Cordova). He has acted as a guest lecturer at the Colombian War College (Escuela Superior de Guerra) and at the Del Rosario University (Colegio Mayor de Nuestra Señora del Rosario). During his career, he has served as liaison officer at the Military and Air Force attaché office of the Embassy of Colombia to the United Kingdom, and assistant to the Military, Naval and Air Force attaché of the Embassy of Colombia to the Russian Federation. His major publications include: '2008 Russian military reform: an adequate response to global threats and challenges of the twenty-first century?' Rev. Cient. Gen. Jose Maria Cordova, vol. 14, no. 17, 2016; 'Full Spectrum Operations: the Rationale behind the 2008 Russian Military Reform?' Rev. Cient. Gen. Jose Maria Cordova, vol. 13, no. 15, 2015; and 'The Challenge of Combat Search and Rescue for Colombian National Army Aviation' Combating Terrorism Exchange (CTX), vol. 3, no. 4, 2013.
\end{abstract}


within a post-peace agreement scenario to gain worldwide recognition, to improve legitimacy, and to establish an alternative source of funding, international experience suggests that the occurrence of several other circumstances is necessary before making such a commitment. The results of a statistical analysis show how the level of implementation of the peace agreement, as well as disarmament, demobilization, reintegration, addressing minority rights, and solving issues with criminal groups are fundamental for deciding on participation in peace operations. Additionally, while international missions may be considered a way of enhancing diplomacy, cautious assessments should be made to determine the military capabilities needed to balance national interests and foreign policy without fostering a regional security dilemma.

\section{Keywords}

Colombia - FARC - implementation - multidimensional peace operations peacekeeping - peace agreement - provisions - United Nations

\section{Introduction}

Over the past three decades, the intricacy of the United Nations' multidimensional peace operations (hereafter UNMDPO), defined as "a mix of military, police, and civilian components working together to lay the foundations of a sustainable peace", ${ }^{1}$ has stimulated growing cooperative work between armed forces and civilian institutions around the world. Since 1948, 71 UNMDPO have been developed to maintain international peace and security under the mandate of the UN Charter and to increase the scope, coverage, and protection of humanitarian assistance. ${ }^{2}$

1 United Nations Department of Peacekeeping Operations, 'United Nations Peacekeeping Operations: Principles and Guidelines', http://www.un.org/en/peacekeeping/documents/capstone _eng.pdf. (accessed 15 October 2017). [Thereafter United Nations Peacekeeping Operations, 2008].

2 United Nations Department of Peacekeeping Operations, 'Current Peacekeeping Operations', http://www.un.org/en/peacekeeping/documents/bnoteo617.pdf. (accessed 16 October 2017). 
Although it is frequently believed outside the peacekeeping community that developed countries are the main contributors to UNMDPO, the current reality is that a small number of developing countries contribute with personnel (military experts, troops, police, and staff officers) in far superior quantities than industrialized states to support such operations. For example, as of June 2017, Ethiopia was contributing 8,221 peacekeepers, Pakistan 7,123, Egypt 3,06o, Burkina Faso 2,933, Senegal 2,820, Ghana 2,752, and Nigeria 1,667. In comparison, China was deploying 2,515, Italy 1,083, Japan 1,012, France 804, Germany 804 , the UK 700 , and the USA $74 \cdot{ }^{3}$ Moreover, it is noteworthy that countries which have solved challenging armed conflicts by peace agreements and that are still striving with complex national scenarios have led participation in UNMDPO by employing their militaries to strengthen foreign policy and gain international recognition by optimizing aid distribution and improving the physical security of humanitarian agencies. For instance, as of June 2017 India was providing 7,676 peacekeepers, Bangladesh 7,013, Rwanda 6,203, Nepal 5,202, Senegal 2,820, Indonesia 2,715, South Africa 1,428, Niger 1,151, Cambodia 823, Burundi 790, and Congo $768 .{ }^{4}$

This trend of participation in UNMDPO by countries which have ended their internal conflicts by peace agreements may be misunderstood at first sight as a strong tendency to be followed by other states with similar characteristics, especially in the absence of relevant literature and comparative studies. This may be so in the case of Colombia as it has recently entered into a peace agreement with the Revolutionary Armed Forces of Colombia (FARC) ${ }^{5}$ but has widely stated its strong intention of participation in UNMDPO with up to three battalions of 5,000 peacekeepers; ${ }^{6}$ disregarding perhaps, the great deal of challenges for the following decade such as the ELN ${ }^{7} \mathrm{EPL},{ }^{8}$ and FARC dissidents,

3 United Nations Department of Peacekeeping Operations, 'Contributors to UN Peacekeeping Operations by Country and Post', http://www.un.org/en/peacekeeping/contributors/2017/ jun17_1.pdf. (accessed 16 October 2017). [Thereafter Contributors to un Peacekeeping Operations, 2017].

4 Contributors to Un Peacekeeping Operations, 2017.

5 FARC stands for Fuerzas Armadas Revolucionarias de Colombia, as per its initials in Spanish.

6 Republic of Colombia - Office of the Press Secretary, 'Colombia aportará tropas a las misiones de mantenimiento de paz de la $O N U$ ', http://wp.presidencia.gov.co/SitePages/DocumentsPDf/ NY_peacekeeping_final.pdf. (accessed 20 September 2017).

7 ELN stands for the National Revolutionary Army, as per its initials in Spanish.

8 EPL stands for the Popular Liberation Army, as per its initials in Spanish. 
the impact of several other organized armed groups; ${ }^{9}$ and its high external debt of more than $41 \%$ of its GDP. ${ }^{10}$

This commitment of the Colombian government, settled with the UN through a framework agreement on January $2015 ;{ }^{11}$ officially announced by the president Juan Manuel Santos Calderon during the 2015 United Nations' leaders' summit on peacekeeping, ${ }^{2}$ and ratified by the Congress of the Republic of Colombia has generated a national debate in Colombia on the appropriateness of the participation of Colombia in UNMDPO given the foreseen multifaceted defense/security scenario, the provisions of the peace agreement that remain outstanding with the FARC, and the scarcity of funds for the years to come. ${ }^{13}$ However, minimal research has been undertaken for the Colombian case, fostering illusive wisdom on the topic.

9 Organized armed groups are defined by the Colombian Ministry of Defense as groups which use violence against the armed forces or other state institutions, civilian populations, civilian property, or other armed groups, with the capacity to generate levels of armed violence that surpass the that of internal disturbances and tensions, with organization, responsible command, and control over a part of the territory. For further analysis, see Colombian Ministry of Defense, 'Directive No.015', https://www.mindefensa.gov.co/ $\mathrm{irj} / \mathrm{go} / \mathrm{km} /$ docs/Mindefensa/Documentos/descargas/Prensa/Documentos/dir_15_2016 .pdf. (accessed 11 September 2017); Eduardo Alvarez, 'Disidencias de las FARC: ¿Por qué lo hacen? ¿Son peligrosas?', (Bogota D.C.: Fundación ideas para la paz, 2016), http://www .ideaspaz.org/publications/posts/1432; Ariel Avila, 'Las disidencias en las FARC', http:// internacional.elpais.com/internacional/2016/12/19/colombia/1482150512_457010.html. (accessed 20 September 2017).

10 David Castaño, 'Deuda externa de Colombia es del $41 \%$ del PIB', http://www.elcolombiano .com/negocios/la-deuda-externa-del-gobierno-subio-4-64-en-un-ano-emisor-KJ5694862. (accessed 24 September 2017).

11 Daniel Valero, 'Colombia entra a la legión de las misiones de seguridad de la ONU', http:// www.eltiempo.com/politica/gobierno/misiones-de-paz-onu-participacion-de-colom bia/16389837 (accessed 26 September 2017); El Tiempo, 'Las cinco claves del acuerdo firmado entre Colombia y la $O N U^{\prime}$, http://www.eltiempo.com/politica/justicia/fuerzas-armadas -participaran-en-misiones-de-paz-en-el-exterior/15152621. (accessed 26 September 2017). Jaime Cubides Cardenas. El Fuero Militar. Justicia interamericana y Operaciones para el Mantenimiento de la Paz (Bogota: Sello Editorial ESMIC, 2017), ISBN: 978-958-59627-6-7.

12 El Heraldo, 'Colombia enviará soldados a misiones de paz de la oNU', http://www.elheraldo .co/nacional/hasta-5000-hombres-mandara-colombia-las-misiones-de-paz-de-la-onu -219776. (accessed 2 October 2017). Vicente Torrijos Rivera and Juan Abella, 'Ventajas y Desventajas Politicas y Militares Para Colombia Derivadas de su Eventual Participación En Misiones Internacionales Relacionados Con La OTAN', Rev. Cient. Gen. Jose Maria Cordova, vol. 15, no. 20, 2017, pp. 47-82, http://dx.doi.org/10.21830/19006586.175.

13 Congress of the Republic of Colombia, Ley 1794 de 2016 por medio de la cual se aprueba el acuerdo marco entre las Naciones Unidas y el gobierno de la República de Colombia relativo 
Hence, this article aims to analyze, by drawing on data on the Peace Accord Matrix (hereafter PAM) of the Kroc Institute for International Peace Studies at the University of Notre Dame and on data from the UN Department of Peacekeeping Operations (hereafter, UN DPKO), the three main reasons used to justify Colombia's participation in UNOMDP: the need to gain international recognition, the need to improve prestige and legitimacy, and the need to seek alternative sources of funding for the armed forces, arguing that considering international experience of 31 countries, the explanations given are inaccurate as they omit key elements for making such a decision.

The first section of this article will provide a summary on the changing character of the UNMDPO across the years. It will then debate conventional wisdom in Colombia on the participation in such operations. Finally, it will provide some insights on the complexity of participating in UNMDPO which may help provide scope and strategies needed for Colombia to be a successful actor on such type of operations.

\section{The Changing Character of the Un Multi-Dimension Peace Operations}

Since the end of the Cold War, there has been an increasing number of intrastate conflicts plagued with human rights violations, ethnic/religious cleansing, and a contempt for human life, making effective UNMD PO more necessary than ever. ${ }^{14}$ Similarly, casualties from UNMDPo have increased as an attempt to combat violence while honoring its non-intervention in domestic affairs policy, as prescribed in Chapter I of the UN charter.

Over the years, the complexity of conflicts and the actors therein have proven that first-generation peace operations (limited to the employment of

a las contribuciones al sistema de acuerdos de fuerzas de reserva de las Naciones Unidas para las operaciones de mantenimiento de la paz, http://leyes.senado.gov.co/proyectos/ index.php/proyectos-ley/periodo-legislativo-2014-2018/2014-2015/article/164 (accessed 4 October 2017).

14 Bruno Simma and Andreas L. Paulus, 'The Responsibility of Individuals for Human Rights Abuses in Internal Conflicts: A Positivist View', American Journal of International Law, vol. 93, no. 2, 1999, pp. 302-16, https://doi.org/10.2307/2997991; Oskar Thoms and James Ron, 'Do Human Rights Violations Cause Internal Conflict?', Human Rights Quarterly, vol. 29, no. 3, 2007, pp. 674-705; Jack Donnelly, Universal Human Rights in Theory and Practice (Ithaca: Cornell University Press, 2013); Dinah Shelton, Remedies in International Human Rights Law (Oxford: Oxford University Press, 2015); Andres E. Fernandez-Osorio, 'Full Spectrum Operations: the Rationale Behind the 2008 Russian Military Reform?', 
troops to monitor ceasefire or disarmament) ${ }^{15}$ and second-generation peace operations (where troops acted as catalyzers among adversaries to prevent conflict $)^{16}$ may be ineffective in scenarios in which comprehensive support for building state capacity and legitimacy is needed. Usually, in a post-peace agreement scenario wherein unsolved grievances fuel the possibility of a relapse into violence and configure an unstable peace environment, it is the military who commences humanitarian tasks and building state-capacity while the situation is controlled and this can then be transferred to civil organizations. However, after some unfortunate experiences, such as the conflicts in the Balkans, Rwanda, and Somalia, where even the credibility of and the need for the UN were questioned, it was recognized that there was a need for a new strategy, called responsibility to protect $\left(\mathrm{R}_{2} \mathrm{P}\right)$, whereby the UN and its members would have the obligation to safeguard human life in the case that state efforts are insufficient in preventing or stopping war crimes, genocide, or crimes against humanity. ${ }^{17}$

The $\mathrm{R}_{2} \mathrm{P}$ policy implies a significant international and comprehensive commitment whereby humanitarian action plays a central role within a carefully designed strategy and a precise combination of peacekeeping and peace enforcement tasks. In other words, it involves multiparty humanitarian efforts led by the UN with civilian peacekeepers and armed forces' assistance (usually known as multidimensional peace operations [MDPO]) or, more specifically, third- (principally involving armed forces) or fourth-generation (principally involving civilian police forces) peacekeeping operations. ${ }^{18}$ Indeed, the UN have described MDPO as operations which are "typically deployed in the dangerous aftermath of a violent internal conflict and may employ a mix of military,

Rev. Cient. Gen. Jose Maria Cordova, vol. 13, no. 15, 2015, pp. 63-86; Chandra Sriram, Olga Martin-Ortega, and Johanna Herman, War, Conflict and Human Rights: Theory and Practice (London: Routledge, 2017).

15 Alex J. Bellamy, 'The next Stage in Peace Operations Theory?', International Peacekeeping, vol. 11, no. 1, 2004, pp. 17-38, https://doi.org/10.1080/1353331042000228436.

16 John Mackinlay and Jarat Chopra, 'Second Generation Multinational Operations', The Washington Quarterly, vol. 15, no. 3, 1992, pp. 113-131, https://doi.org/10.1080/016366o920 9550110.

17 Ken Simons, 'Sovereignty and Responsibility to Protect', Peace Magazine, vol. 19, no. 1, 2003, p. 23.

18 See Mark Malan, 'Peacekeeping in the New Millennium: Towards Fourth Generation Peace Operations?', African Security Review, vol. 7, no. 3, 1998, pp. 13-20, https://doi.org/ 10.1080/10246029.1998.9627861; Kai Kenkel, 'Five Generations of Peace Operations: From the thin Blue Line to painting a Country Blue', Revista Brasileira de Política Internacional, vol. 56, no. 1, 2013, pp. 122-143. 
police, and civilian capabilities to support the implementation of a comprehensive peace agreement."19

Although such civil-military cooperation may improve the effectiveness of UNMDPO by the utilization of the capabilities of the military and its experience, it has also generated some dilemmas for contributing nations which challenge the rationale for the need for participation in such operations. For instance, Gourlay, ${ }^{20}$ Pugh, ${ }^{21}$ Guttieri, ${ }^{22}$ Coning, ${ }^{23}$ Bruneau and Matei, ${ }^{24}$ Hultman, ${ }^{25}$ Diehl and Balas, ${ }^{26}$ Lucius and Rietjens, ${ }^{27}$ and Rudolf ${ }^{28}$ considered the contradiction in the principles of UNMDPO: the humanity, neutrality, impartiality, and independence of humanitarian actions led, accompanied, or supported by armed forces. ${ }^{29}$ Similarly, George, ${ }^{30}$ Ankersen, ${ }^{31}$ Bove and Elia, ${ }^{32}$

19 United Nations Peacekeeping Operations, 2008.

20 Catriona Gourlay, 'Partners Apart: Managing Civil-Military Co-Operation in Humanitarian Interventions', Disarmament Forum, vol. 3, 2000, pp. 33-44.

21 Michael Pugh, 'The Challenge of Civil-Military Relations in International Peace Operations', Disasters, vol. 25, no. 4, 2001, pp. 345-357, https://doi.org/10.1111/1467-7717.00183.

22 Karen Guttieri, 'Civil-Military Relations in Peacebuilding', Sicherheit Und Frieden $(S+F)$ / Security and Peace, vol. 22, no. 2, 2004, pp. 79-85.

23 Cedric de Coning, 'Civil-Military Coordination and un Peacebuilding Operations', African Journal on Conflict Resolution, vol. 5, no. 2, 2005, pp. 89-118.

24 Thomas C. Bruneau and Florina Cristiana Matei, 'Towards a New Conceptualization of Democratization and Civil-Military Relations', Democratization, vol. 15, no. 5, 2008, pp. 909-29, https://doi.org/10.1080/13510340802362505.

25 Lisa Hultman, 'Keeping Peace or Spurring Violence? Unintended Effects of Peace Operations on Violence against Civilians', Civil Wars, vol. 12, no. 1-2, 2010, pp. 29-46, https://doi .org/10.1080/13698249.2010.484897.

26 Paul F. Diehl and Alexandru Balas, Peace Operations (New Jersey:John Wiley \& Sons, 2014).

27 Gerard Lucius and Sebastiaan Rietjens, Effective Civil-Military Interaction in Peace Operations: Theory and Practice (New York: Springer, 2016).

28 Peter Rudolf, 'Un Peace Operations and the Use of Military Force', Survival, vol. 59, no. 3, 2017, pp. 161-182, https://doi.org/10.1080/00396338.2017.1325605.

29 United Nations Office for the Coordination of Humanitarian Affairs, Humanitarian Principles, https://docs.unocha.org/sites/dms/Documents/OOM-humanitarianprinciples _eng_June12.pdf. (accessed 24 September 2017).

30 Aurelia George, 'Japan's Participation in U.N. Peacekeeping Operations: Radical Departure or Predictable Response?', Asian Survey, vol. 33, no. 6, 1993, pp. 56o-575, https://doi .org/10.2307/2645006.

31 Christopher Ankersen, Civil-Military Cooperation in Post-Conflict Operations: Emerging Theory and Practice (London: Routledge, 2007).

32 Vincenzo Bove, 'Supplying Peace: Participation in and Troop Contribution to Peacekeeping Missions', Journal of Peace Research, vol. 48, no. 6, 2010, pp. 699-714. 
Dorussen, ${ }^{33}$ Badmus, ${ }^{34}$ Yamashita, ${ }^{35}$ Abba, Osman, and Muda, ${ }^{36}$ Philippe Duffort, ${ }^{37}$ and Kathman and Melin ${ }^{38}$ referred to the shortcomings of involving armed forces in foreign policy and resolving alien tensions while they are still needed in their countries to address the threats and challenges of a globalized world.

This perception is especially critical for countries seeking participation in the international arena but which are still striving to implement peace agreements, consolidate a stable post-accord scenario, and deal with financial burdens. This is because their participation raises questions on the advantages of participation in UNMDPO and the potential consequences thereof. UNMDPO are a permanent challenge to their actors because of the complex interdependence between decisions and their subsequent effects. An erroneous understanding of new participants on the purpose of the troops, military experts, or staff personnel may lead to adverse consequences in terms of damage to the credibility of humanitarian aid and its accompanying security scenario. ${ }^{39}$

\section{Debating Conventional Wisdom on UNMDPo in Colombia}

Since the signing of the peace agreement with the FARC in November 2016, conventional wisdom in Colombia on defense/security matters is of the opinion that countries emerging from armed conflicts by peace agreements no

33 Han Dorussen, 'More than Taxi-Drivers? Pitfalls and Prospects of Local Peacekeeping', https://sustainablesecurity.org/2016/og/o1/more-than-taxi-drivers-pitfalls-and-pros pects-of-local-peacekeeping/. (accessed 30 September 2017).

34 Isiaka Badmus, 'The African Union's Role in Peacekeeping: Building on Lessons Learned from Security Operations' (London: Palgrave Macmillan, 2015).

35 Hikaru Yamashita, 'Debating Peacekeeping Cooperation at Multiple Levels', International Peacekeeping, vol. 23, no. 2, 2016, pp. 358-362, https://doi.org/10.1080/13533312.2015.113506o.

36 Mahdi Abubakar Abba, Nazariah Binti Osman and Muhammad Bin Muda, 'Internal Security Challenges and the Dilemma of Troop's Contribution to un Peacekeeping Operations: The Nigeria's Experience', International Journal of Management Research \& Review, vol. 7, no. 4, 2017, pp. 398-417.

37 Philippe Duffort, Clausewitz y sociedad. Una introducción biográfica a las lecturas neoclausewitzianas (Bogotá: Sello Editorial ESMIC, 2017), ISBN: 9789585962736.

38 'Who Keeps the Peace? Understanding State Contributions to UN Peacekeeping Operations', International Studies Quarterly, vol. 61, no. 1, 2017, pp. 150-162, https://doi.org/ 10.1093/isq/sqw041.

39 Bethan K. Greener, 'The Rise of Policing in Peace Operations', International Peacekeeping, vol. 18, no. 2, 2011, pp. 183-195, https://doi.org/10.1080/13533312.2011.546og6; David Curran, 'Towards the Military Conflict Resolution Practitioner?', in More than Fighting for Peace?, 
longer require the same military capabilities and, hence, their armed forces should be transformed to address new threats and challenges and to redirect some of their experience to support international missions as a way of raising funds and encouraging self-sufficiency. ${ }^{40}$ While some Officials, the military and sectors of academia have praised this commitment as possibly strengthening foreign policy, advertising Colombian military capabilities and experience abroad, and redirecting funding to more sensitive areas ${ }^{41}$ some experts and think tanks disagree and maintain that there are many tasks for the armed forces to fulfill in Colombia and that reducing their budget and contributing personnel and equipment to UNMDPO will weaken the necessary efforts to secure areas vacated by the FARC and to address other threats. ${ }^{42}$

The Anthropocene: Politik - Economics - Society - Science (London: Springer, 2017), pp. 115-133, https://doi.org/10.1007/978-3-319-46305-6_6; Chiara Ruffa, 'Military Cultures and Force Employment in Peace Operations', Security Studies, vol. 26, no. 3, 2017, pp. 391-422, https://doi.org/10.1080/o9636412.2017.1306393.

40 Miguel Cardenas, 'La construccion del posconflicto en Colombia: enfoques desde la pluralidad' (Bogota D.C.: Friedrich Ebert Stiftung, 2003), http://biblioteca.cinep.org.co:1008o/ cgi-bin/koha/opac-detail.pl?biblionumber=23240; Carlos Martinez, 'Las Fuerzas Militares y de Policía en el postconflicto colombiano', Derecho y Realidad, vol. 24, no. 2, 2014, pp. 300-314; Sandra Cardenas and Ingrid Petro, "Rol de las Fuerzas Armadas y de Policía en el marco del posconflicto colombiano," Verba Iuris, vol. 32, no. 3, 2014, pp. 149-162; Orlando Alarcon, 'Sostenibilidad de la economía de defensa colombiana con la participación en Operaciones de Paz', http://repository.unimilitar.edu.co/handle/10654/12888 (accessed 4 October 2017); Maria Ruiz, John Galeano, and Edwin Gil, 'Posconflicto colombiano y sus efectos económicos', Revista CIFE: Lecturas de Economía Social, vol. 17, no. 27, 2016, pp. 23-54, https://doi.org/10.15332/s0124-3551.2015.0027.01; Wilson Acosta, 'El postconflicto y el gasto público: un desafío para Colombia', http://repository.unimilitar.edu.co/ handle/10654/7809 (accessed 4 October 2017); Carlos Herran, 'Roles del sector Defensa Nacional en el posconflicto combiano', http://repository.unimilitar.edu.co/handle/10654/7144 (accessed 5 October 2017); Ana Zacarias, 'Un país unido que se imagina la paz', http:// colombia202o.elespectador.com/opinion/un-pais-unido-que-se-imagina-la-paz-ana -paula-zacarias (accessed 6 October 2017); Tom Odebrecht, 'Hacia una Colombia menos militarizada', http://colombia2o2o.elespectador.com/opinion/hacia-una-colombia-me nos-militarizada (accessed 6 October 2017); Jorge Abella and Kevin Lesmes, 'El camino al posconflicto: referencias y enseñanzas hacia la paz', Ploutos, vol. 7, no. 1, 2016, pp. 40-46.

41 German Vallejo, 'Las Operaciones de Paz de la oNU: una opción para el caso colombiano' (Bogota D.c.: Universidad Catolica de Colombia, 2015), http://publicaciones.ucatolica .edu.co/uflip/las-operaciones-de-paz-de-la-ONU/pubData/source/Las-operaciones-de -paz-de-la-ONU.pdf; Luis Villegas, 'Carta del ministro de defensa a los soldados y policías', https://www.ejercito.mil.co/?idcategoria=397563 (accessed 7 October 2017).

42 Elber Gutierrez and Marcela Osorio, '¿A qué se van a dedicar las Fuerzas Armadas en el posconflicto?', http://colombia202o.elespectador.com/politica/que-se-van-dedicar-las 
Participating in international missions is not a new task for the Colombian armed forces, ${ }^{43}$ as they participated in the Korean War for almost two years (1951-1953) with an infantry battalion of 4,750 soldiers and three frigates. ${ }^{44}$ In fact, since 1982, the National Army of Colombia has maintained an infantry battalion in the Sinai Peninsula as part of the independent multinational force and observers (M FO) overseeing the terms of the peace agreement between Israel and Egypt; ${ }^{45}$ and the National Police ${ }^{46}$ has contributed more than 100 officers to the Un Stabilization Mission in Haiti. Likewise, the Colombian Navy ${ }^{47}$ participated in international maritime security operations in the Indian Ocean, the Horn of Africa, and the Gulf of Oman; and according to the Colombian Ministry of Defense, since 2010, the armed forces have trained more than 29,000 servicemen and women from other countries under defense/security regional agreements. ${ }^{48}$ However, limited participation has had Colombian armed forces in UNMDPO where diplomacy and effective conflict-resolution tasks are needed, especially under duress in conditions such as those of Mali (MINUSMA), Darfur (UNAMID), or Lebanon (UNIFIL) with a duration of several years or with multiple casualties caused by malicious acts or illness (Appendix 1 and 2 ).

-fuerzas-armadas-en-el-posconflicto (accessed 10 august 2017); Ricardo Monsalve, 'Colombia exportará más militares a misiones de la oNU' http://www.elcolombiano.com/ colombia/colombia-ofrecera-a-la-onu-ampliar-su-participacion-militar-en-misiones-de -paz-XN6618653 (accessed 22 august 2017).

43 Understood as the military forces (Army, Navy, and Air Force) and the national police.

44 Adolfo Atehortua, 'Colombia en la guerra de Corea', Folios, vol. 2, no. 27, 2008, pp. 63-76; Arturo Wallace, 'Los soldados colombianos que combatieron en la guerra de Corea' http:// www.bbc.com/mundo/noticias/2013/07/130724_america_latina_colombia_soldados_vet eranos_guerra_corea_aw (accessed 18 july 2017); Juan Melendez, 'Colombia y su participación en la guerra de Corea: una relexión tras 64 años de iniciado el conlicto', Historia y Memoria, vol. 25, no. 10, 2015, pp. 199-239.

45 National Army of Colombia, 'Batallón Colombia No. 3, Más de 3 o Años de Historia - Ejercito Nacional de Colombia, https://www.ejercito.mil.co/conozcanos/sinai_mision_paz/ (accessed 24July 2017); Multinational Force and Observers, 'MFO - the Multinational Force \& Observers', http://mfo.org/en/mission-begins (accessed 2 September 2017).

46 National Police of Colombia, 'Colombia envía viI contingente de policías para apoyar la misión de la oNU en Haití', https://www.policia.gov.co/noticia/colombia-env\% $\mathrm{C}_{3} \%$ ADa-vii-contingente-de-polic $\% \mathrm{C}_{3} \% \mathrm{ADas}$-para-apoyar-la-misi $\% \mathrm{C}_{3} \% \mathrm{~B} 3 n$-de-la-onu-en -hait\% $\mathrm{C}_{3} \% \mathrm{AD}$ (accessed 23 August 2017).

47 Colombian Navy, 'Finaliza participacion colombiana en operaciones de seguridad marítima en África', https://www.armada.mil.co/es/content/finaliza-participacion-colombiana -en-operaciones-de-seguridad-maritima-en-africa (accessed 3 September 2017).

48 Colombian Ministry of Defense, 'Memorias al Congreso 2015-2016', https://www.mind efensa.gov.co/irj/go/km/docs/Mindefensa/Documentos/descargas/Documentos_Des 
Despite the importance of this discussion for Colombia and the undeniable influence thereof on foreign affairs, the literature on this complex national dilemma is still scarce and insufficient. Limited academic analyses have been carried out with the aim of assessing the reasons for and perspectives on the initiative of participation in UNMDPO and its correlation with the much-quoted international experience. For instance, in this debate in Colombia, the impact of the level of implementation of the peace agreement on the participation of the armed forces in UNMDPO or the existence of other persistent armed groups have been ignored. Similarly, the accomplishment of peace agreement provisions such as "disarmament," "demobilization," "reintegration," and "human rights" has been disregarded as well.

To determine the trends in the international experience of countries which have solved their internal armed conflicts by peace agreements and its possible correlation with contributing personnel (military experts, troops, police, and staff officers) to UNMDPO, an analysis of data from the PAM of the Kroc Institute for International Peace Studies at the University of Notre Dame and data from the UN DPKO was undertaken. On the one hand, the PAM provides a characterization of peace agreements in 31 countries between 1989 and $2012^{49}$ in the light of $5^{1}$ types of provisions (Table 1). Likewise, it provides data regarding the implementation level of the peace agreements 10 years after the signature of the final document (Table 2). On the other hand, the UN DP KO provides official data on the contribution of personnel by countries to UNMDPO.

A regression analysis was undertaken based on these two datasets. The dependent variable "contribution of personnel to UNMDPO" (measured in terms of the number of peacekeepers) was analyzed against a set of $5^{2}$ predictors: one independent variable "level of implementation" (measured between 0-100\%) and $5^{1}$ dummy variables (the provisions of the PAM described in Table 3 such as "amnesty", "arms embargo", "boundary demarcation", and "cease fire" measured "yes" or "not"). The predictors were divided into four groups to facilitate the analysis. Appendices 3 to 6 describe the results of the regression analysis.

cargables/espanol/memorias2015-2016.pdf (accessed 23 August 2017); Arlene Tickner, 'Exportación de la seguridad y política exterior de Colombia' (Bogota D.C.: Friedrich Ebert Stiftung, 2016), http://library.fes.de/pdf-files/bueros/kolumbien/12773.pdf [Thereafter Tickner, 2016].

49 A full explanation of Kroc's Peace Accords Matrix provisions, methodology, and definitions has been undertaken by Joshi Madhav, Jason M. Quinn, and Patrick M. Regan, 'Annualized Implementation Data on Intrastate Comprehensive Peace Accords, 1989-2012', Journal of Peace Research, vol. 52, no. 4, 2015, pp. 551-62 [Thereafter Madhav, Quinn and Regan, 2015]; additional information can be found on the webpage of the Kroc Institute for International Peace Studies, University of Notre Dame at https://peaceaccords .nd.edu/about. 


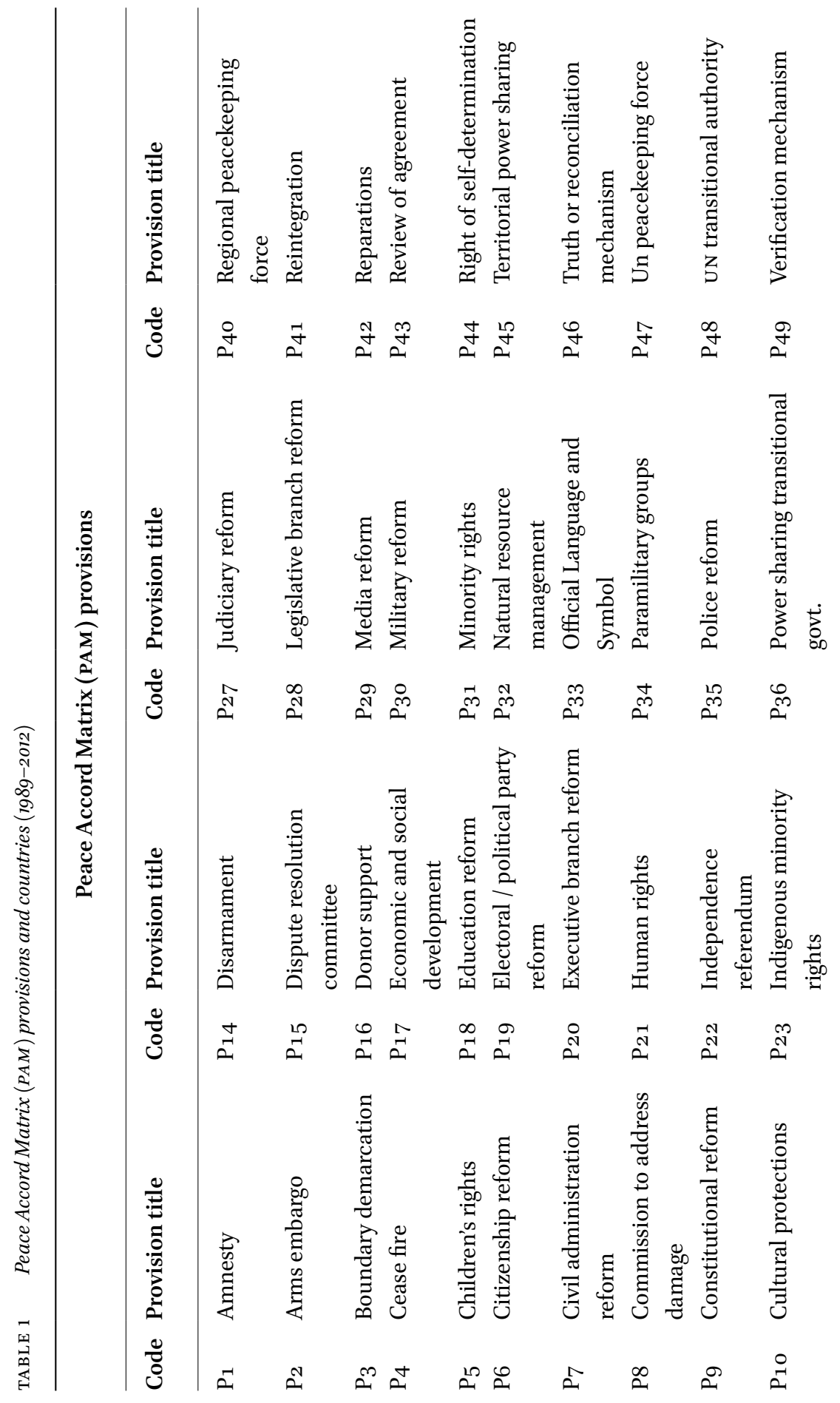




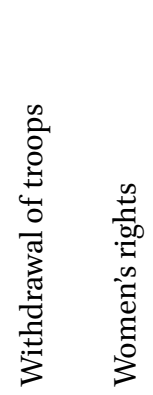

in in

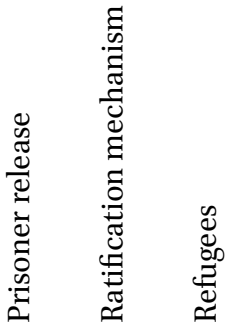

命 市

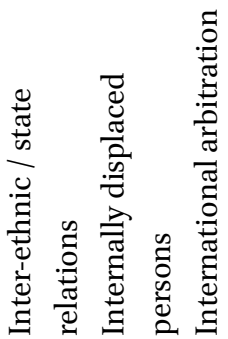

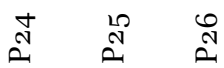

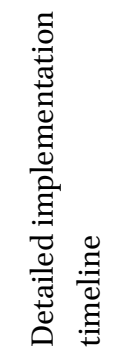

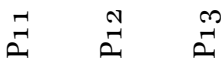

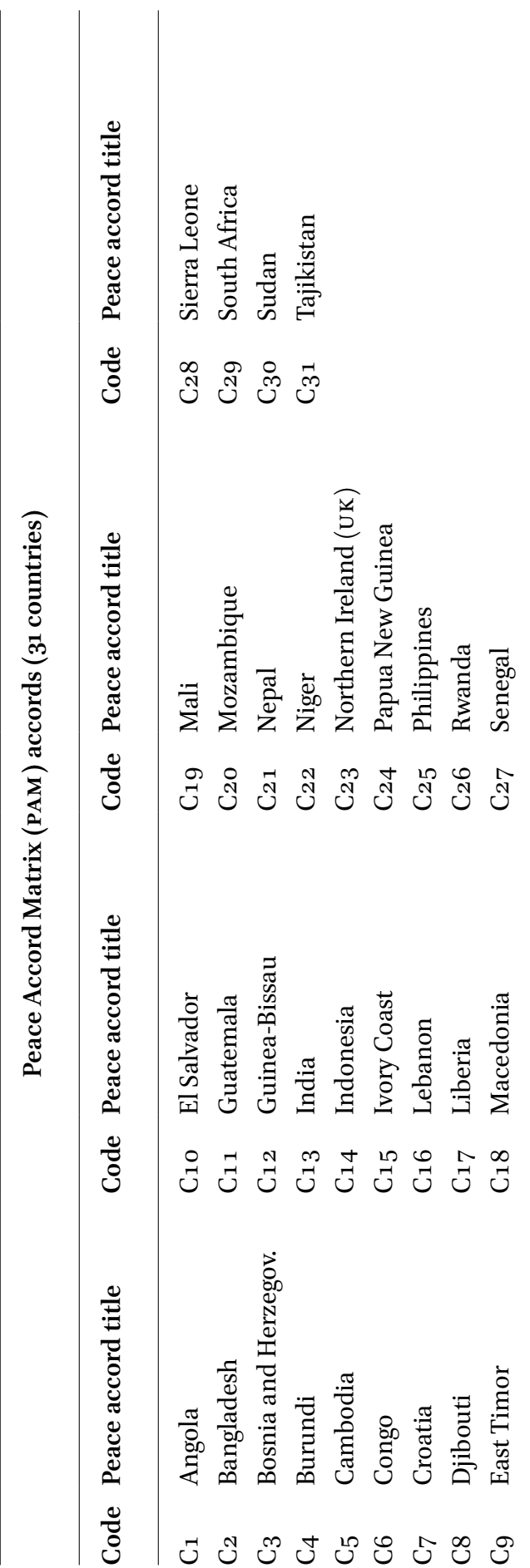

$\ddot{\bar{N}}$

iे

त

密

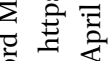

80

4 \&

$\mathscr{\varpi}$

$2 \lambda$

in

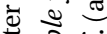

屯

¿

焉要

空芯

iิ

苛

$\checkmark \circlearrowleft$

चे

क ठ

छ

긍

के क्षे

उี

ت

㻤 :

응

ช

¿

ป ะ

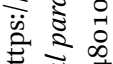

E्ञ

अर है

$\frac{8}{2} \frac{2}{8}$

क्ष

낭

进

\&

\&

$\therefore \frac{\infty}{8}$

气ี

๑็ ฮี

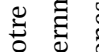

굥

to on

충 중

: 


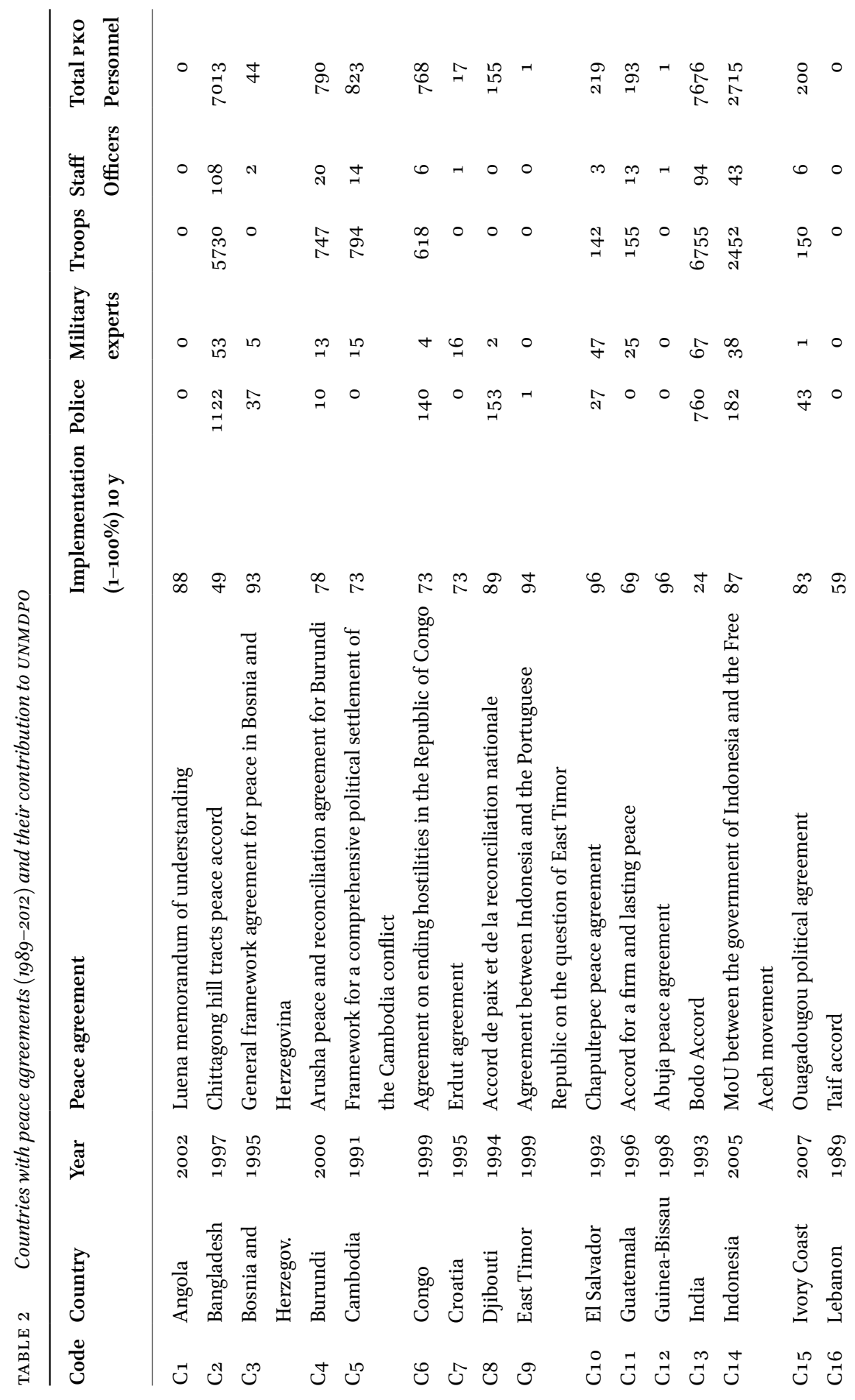




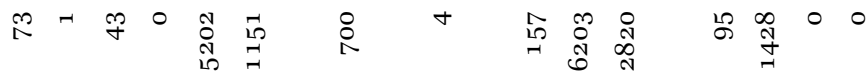

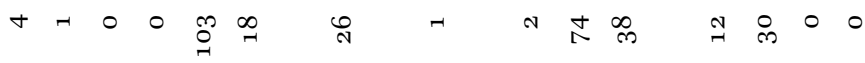

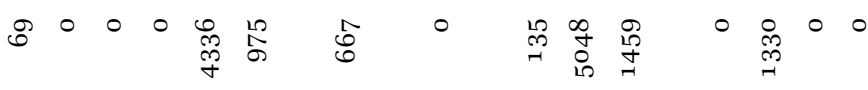

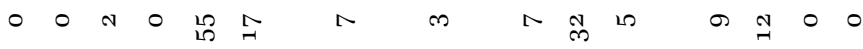

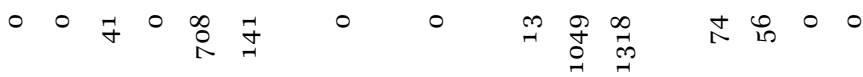

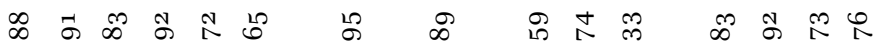

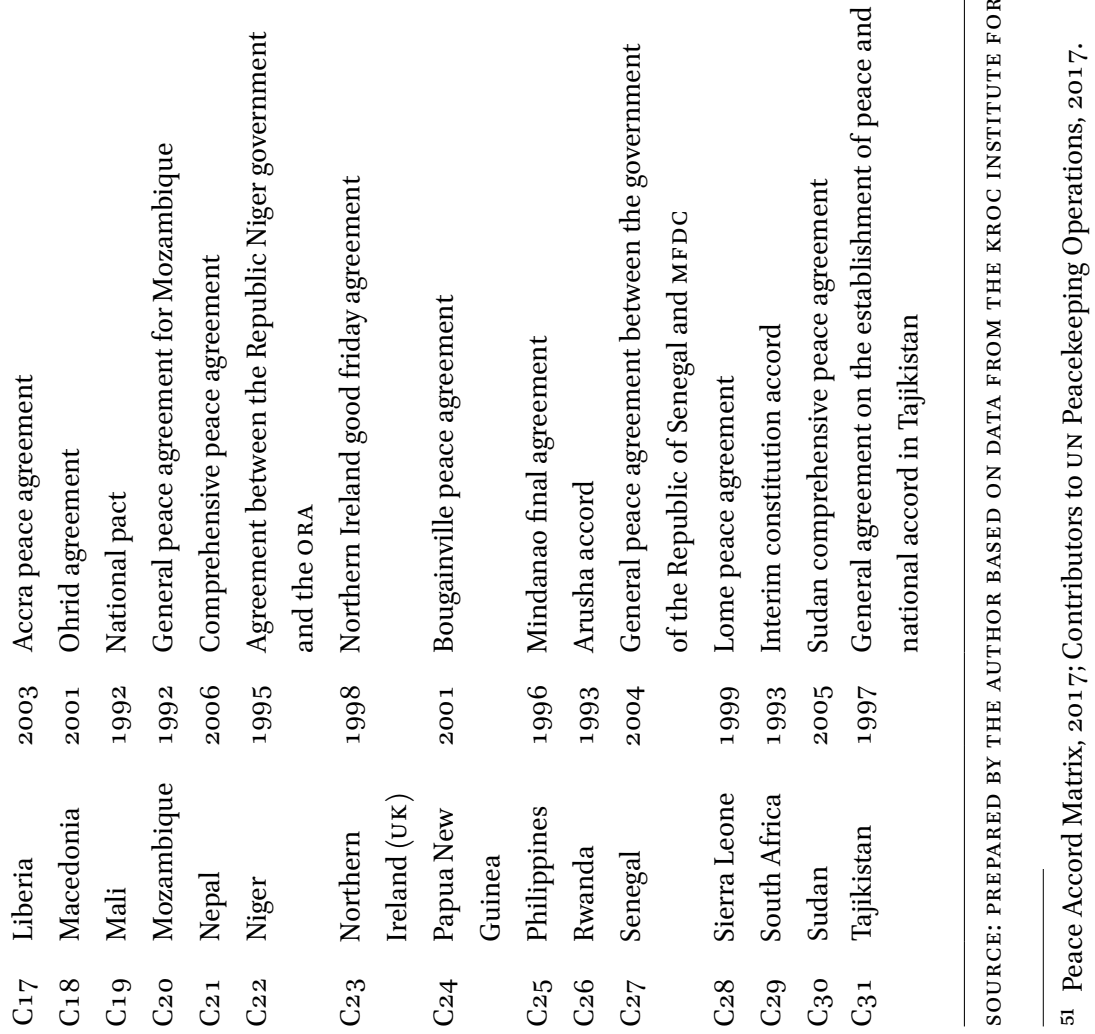


TABLE 3 Countries with peace agreements (1989-2012) and the occurrence of PAM's provisions on each case $($ Yes $=1$, No $=o)$

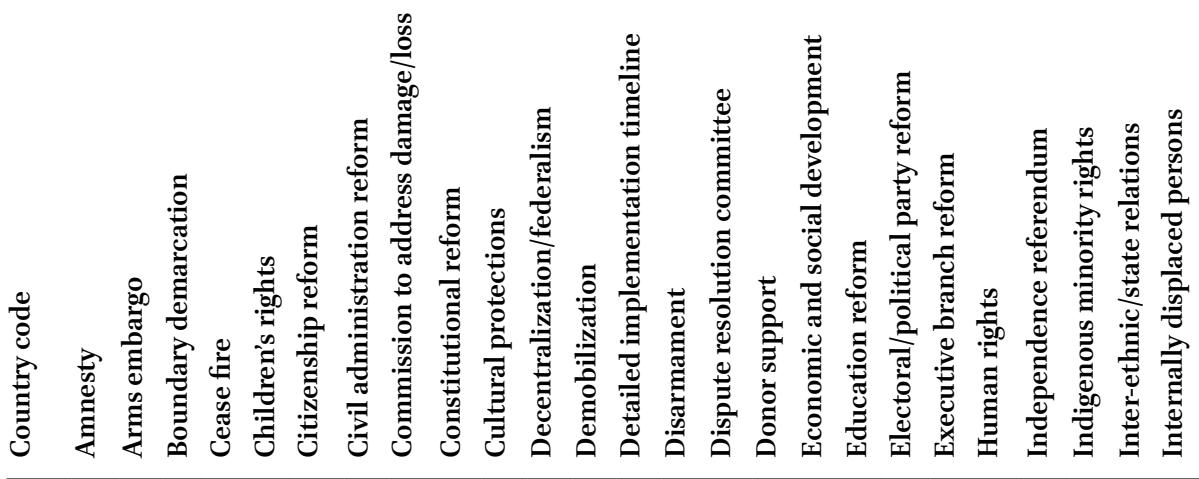
$\begin{array}{lllllllllllllllllllllllllll}\mathrm{C} 2 & 1 & 0 & 0 & 0 & 0 & 1 & 0 & 0 & 0 & 0 & 1 & 1 & 0 & 1 & 0 & 0 & 1 & 0 & 1 & 0 & 0 & 0 & 1 & 0 & 1\end{array}$ $\begin{array}{llllllllllllllllllllllllll}\mathrm{C}_{3} & 1 & 0 & 1 & 1 & 0 & 1 & 0 & 0 & 1 & 1 & 1 & 0 & 1 & 0 & 1 & 0 & 1 & 0 & 1 & 1 & 1 & 0 & 0 & 0 & 1\end{array}$ $\begin{array}{llllllllllllllllllllllllll}\mathrm{C}_{4} & 1 & 0 & 0 & 1 & 1 & 0 & 1 & 0 & 1 & 0 & 0 & 1 & 1 & 1 & 1 & 1 & 1 & 1 & 1 & 1 & 1 & 0 & 0 & 0 & 1\end{array}$

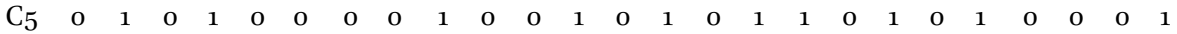

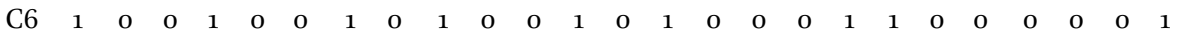
$\begin{array}{llllllllllllllllllllllllll}\mathrm{C}_{7} & 0 & 0 & 0 & 0 & 0 & 1 & 0 & 0 & 0 & 0 & 0 & 0 & 0 & 1 & 0 & 0 & 0 & 0 & 0 & 0 & 1 & 0 & 0 & 1 & 1\end{array}$

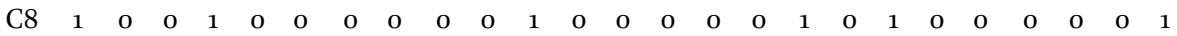
C9 $\begin{array}{llllllllllllllllllllllllll} & 0 & 0 & 0 & 0 & 0 & 0 & 0 & 0 & 1 & 0 & 0 & 0 & 1 & 1 & 0 & 1 & 0 & 0 & 0 & 0 & 0 & 1 & 0 & 0 & 0\end{array}$ $\begin{array}{llllllllllllllllllllllllll}\mathrm{C} 10 & 0 & 0 & 0 & 1 & 0 & 0 & 1 & 0 & 1 & 0 & 0 & 1 & 1 & 1 & 1 & 1 & 1 & 0 & 1 & 0 & 1 & 0 & 0 & 0 & 1\end{array}$ $\begin{array}{lllllllllllllllllllllllllll}\mathrm{C}_{11} & 1 & 0 & 0 & 1 & 0 & 0 & 1 & 0 & 1 & 1 & 1 & 1 & 1 & 1 & 0 & 1 & 1 & 1 & 1 & 1 & 1 & 0 & 1 & 1 & 1\end{array}$ $\begin{array}{llllllllllllllllllllllllll}\mathrm{C} 12 & 0 & 0 & 0 & 1 & 0 & 0 & 0 & 0 & 0 & 0 & 0 & 0 & 1 & 0 & 0 & 0 & 0 & 0 & 0 & 0 & 0 & 0 & 0 & 0 & 1\end{array}$ $\begin{array}{llllllllllllllllllllllllll}\mathrm{C}_{13} & 1 & 0 & 1 & 0 & 0 & 0 & 1 & 0 & 0 & 1 & 1 & 1 & 0 & 1 & 0 & 0 & 1 & 1 & 0 & 0 & 0 & 0 & 1 & 0 & 0\end{array}$ $\begin{array}{llllllllllllllllllllllllll}\mathrm{C} 14 & 1 & 0 & 1 & 1 & 0 & 1 & 0 & 1 & 0 & 1 & 1 & 1 & 1 & 1 & 1 & 0 & 1 & 0 & 1 & 0 & 1 & 0 & 0 & 0 & 0\end{array}$ $\begin{array}{llllllllllllllllllllllllll}\mathrm{C}_{15} & 1 & 1 & 0 & 1 & 0 & 1 & 1 & 0 & 0 & 0 & 0 & 1 & 1 & 1 & 1 & 0 & 0 & 0 & 1 & 0 & 0 & 0 & 0 & 0 & 1\end{array}$ $\begin{array}{llllllllllllllllllllllllll}\mathrm{C} 16 & 0 & 0 & 0 & 0 & 0 & 0 & 1 & 0 & 0 & 0 & 1 & 0 & 1 & 0 & 1 & 0 & 1 & 1 & 1 & 1 & 0 & 0 & 0 & 0 & 1\end{array}$ $\begin{array}{llllllllllllllllllllllllll}\mathrm{C}_{17} & 1 & 0 & 0 & 1 & 1 & 0 & 1 & 0 & 1 & 0 & 1 & 1 & 1 & 1 & 1 & 1 & 1 & 0 & 1 & 0 & 1 & 0 & 0 & 0 & 1\end{array}$ $\begin{array}{llllllllllllllllllllllllll}\mathrm{C} 18 & 0 & 0 & 1 & 1 & 0 & 0 & 1 & 0 & 1 & 0 & 1 & 0 & 1 & 1 & 0 & 1 & 0 & 1 & 1 & 0 & 0 & 0 & 1 & 0 & 1\end{array}$ $\begin{array}{llllllllllllllllllllllllll}\text { C19 } & 0 & 0 & 0 & 1 & 0 & 0 & 1 & 0 & 0 & 0 & 1 & 1 & 1 & 1 & 1 & 1 & 1 & 0 & 0 & 0 & 0 & 0 & 0 & 0 & 0\end{array}$ $\begin{array}{llllllllllllllllllllllllll}\mathrm{C} 2 \mathrm{O} & 1 & 0 & 0 & 1 & 0 & 0 & 0 & 0 & 1 & 0 & 0 & 1 & 1 & 1 & 1 & 1 & 0 & 0 & 1 & 1 & 1 & 0 & 0 & 0 & 1\end{array}$ $\begin{array}{llllllllllllllllllllllllll}\mathrm{C} 21 & 0 & 0 & 0 & 1 & 1 & 0 & 0 & 0 & 1 & 0 & 1 & 1 & 1 & 1 & 1 & 1 & 1 & 1 & 1 & 1 & 1 & 0 & 1 & 1 & 1\end{array}$ $\begin{array}{llllllllllllllllllllllllll}\mathrm{C} 22 & 1 & 0 & 0 & 1 & 0 & 0 & 0 & 0 & 0 & 1 & 1 & 1 & 0 & 1 & 1 & 1 & 1 & 1 & 0 & 0 & 0 & 0 & 0 & 0 & 0\end{array}$ $\begin{array}{llllllllllllllllllllllllll}\mathrm{C} 23 & 0 & 0 & 0 & 1 & 0 & 1 & 0 & 0 & 1 & 0 & 1 & 1 & 1 & 1 & 1 & 0 & 1 & 1 & 1 & 0 & 1 & 1 & 0 & 1 & 0\end{array}$ $\begin{array}{llllllllllllllllllllllllll}\mathrm{C} 24 & 1 & 0 & 1 & 1 & 0 & 0 & 1 & 0 & 1 & 0 & 1 & 0 & 1 & 1 & 1 & 1 & 1 & 0 & 1 & 1 & 1 & 1 & 0 & 0 & 0\end{array}$ $\begin{array}{lllllllllllllllllllllllllll}\mathrm{C} 25 & 0 & 0 & 1 & 1 & 0 & 0 & 1 & 0 & 1 & 1 & 1 & 0 & 1 & 0 & 0 & 1 & 1 & 1 & 0 & 1 & 1 & 0 & 0 & 1 & 0\end{array}$ $\begin{array}{llllllllllllllllllllllllll}\mathrm{C} 26 & 0 & 0 & 0 & 1 & 0 & 1 & 1 & 0 & 1 & 0 & 0 & 1 & 1 & 1 & 0 & 1 & 1 & 0 & 1 & 1 & 1 & 0 & 0 & 1 & 1\end{array}$ 


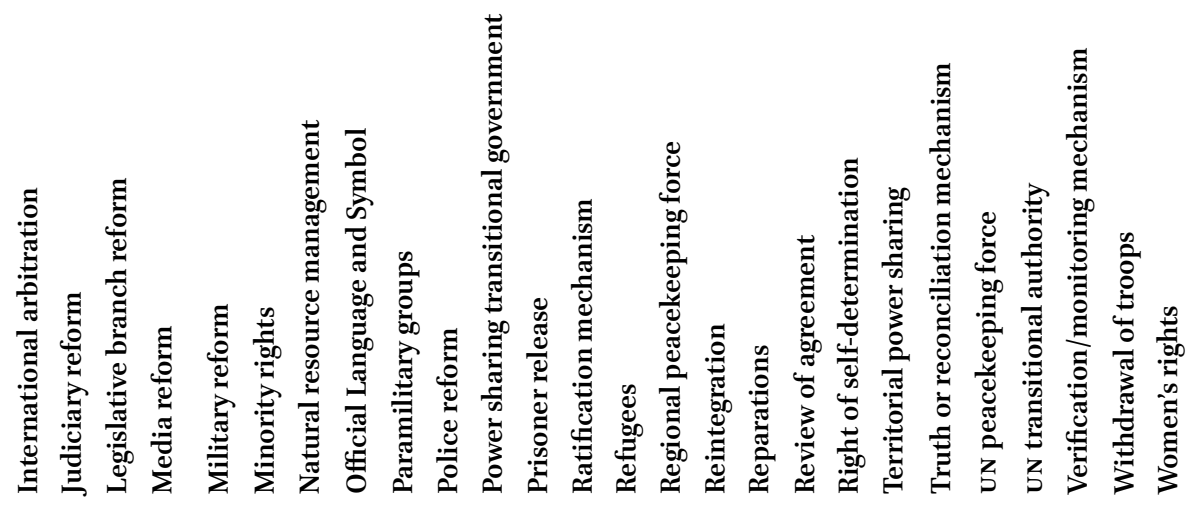

\footnotetext{
$\begin{array}{llllllllllllllllllllllllll}0 & 0 & 0 & 1 & 1 & 0 & 0 & 0 & 1 & 1 & 1 & 0 & 0 & 0 & 0 & 1 & 0 & 0 & 0 & 0 & 0 & 0 & 0 & 1 & 1 & 0\end{array}$ $\begin{array}{lllllllllllllllllllllllllll}0 & 0 & 0 & 0 & 0 & 0 & 0 & 0 & 0 & 1 & 0 & 1 & 0 & 1 & 0 & 1 & 0 & 0 & 0 & 0 & 0 & 0 & 0 & 1 & 1 & 0\end{array}$ $\begin{array}{llllllllllllllllllllllllll}1 & 0 & 1 & 0 & 0 & 0 & 0 & 0 & 1 & 0 & 1 & 1 & 0 & 1 & 0 & 0 & 0 & 0 & 0 & 1 & 0 & 1 & 0 & 1 & 1 & 0\end{array}$ $\begin{array}{llllllllllllllllllllllllll}0 & 1 & 0 & 1 & 1 & 1 & 1 & 0 & 1 & 1 & 1 & 1 & 1 & 1 & 1 & 1 & 0 & 1 & 0 & 0 & 1 & 1 & 0 & 1 & 1 & 1\end{array}$ $\begin{array}{llllllllllllllllllllllllll}0 & 1 & 0 & 0 & 1 & 0 & 0 & 0 & 1 & 0 & 1 & 1 & 0 & 1 & 0 & 1 & 0 & 0 & 0 & 0 & 0 & 1 & 1 & 1 & 1 & 0\end{array}$ $\begin{array}{lllllllllllllllllllllllllll}0 & 0 & 0 & 0 & 1 & 0 & 0 & 0 & 1 & 1 & 0 & 1 & 0 & 1 & 0 & 1 & 0 & 0 & 0 & 0 & 0 & 0 & 0 & 1 & 0 & 0\end{array}$ $\begin{array}{lllllllllllllllllllllllllll}0 & 0 & 0 & 0 & 0 & 0 & 0 & 0 & 0 & 1 & 0 & 0 & 0 & 1 & 0 & 0 & 0 & 0 & 0 & 0 & 0 & 1 & 1 & 1 & 0 & 0\end{array}$ $\begin{array}{llllllllllllllllllllllllll}0 & 0 & 0 & 0 & 1 & 0 & 0 & 0 & 0 & 0 & 0 & 0 & 0 & 1 & 0 & 1 & 0 & 0 & 0 & 0 & 0 & 0 & 0 & 0 & 0 & 0\end{array}$ $\begin{array}{lllllllllllllllllllllllllll}0 & 0 & 0 & 0 & 0 & 0 & 0 & 0 & 0 & 1 & 0 & 0 & 0 & 0 & 0 & 0 & 0 & 0 & 1 & 0 & 0 & 1 & 1 & 1 & 1 & 0\end{array}$ $\begin{array}{llllllllllllllllllllllllll}0 & 1 & 0 & 1 & 1 & 0 & 1 & 0 & 1 & 1 & 0 & 1 & 0 & 1 & 0 & 1 & 0 & 1 & 0 & 0 & 1 & 0 & 0 & 1 & 0 & 0\end{array}$ $\begin{array}{llllllllllllllllllllllllll}0 & 1 & 1 & 1 & 1 & 0 & 1 & 1 & 1 & 1 & 0 & 0 & 0 & 1 & 0 & 1 & 1 & 0 & 0 & 0 & 1 & 0 & 0 & 1 & 0 & 1\end{array}$ $\begin{array}{lllllllllllllllllllllllllll}0 & 0 & 0 & 0 & 0 & 0 & 0 & 0 & 0 & 0 & 1 & 0 & 0 & 1 & 1 & 0 & 0 & 0 & 0 & 0 & 0 & 0 & 0 & 1 & 1 & 0\end{array}$ $\begin{array}{lllllllllllllllllllllllllllllllllllllllll}0 & 1 & 0 & 0 & 1 & 1 & 0 & 1 & 0 & 1 & 0 & 0 & 0 & 0 & 0 & 1 & 1 & 0 & 0 & 0 & 0 & 0 & 0 & 0 & 0 & 0\end{array}$ $\begin{array}{lllllllllllllllllllllllllll}0 & 1 & 0 & 1 & 1 & 0 & 1 & 1 & 0 & 1 & 0 & 1 & 0 & 0 & 0 & 1 & 1 & 0 & 0 & 0 & 1 & 0 & 0 & 1 & 0 & 0\end{array}$ $\begin{array}{lllllllllllllllllllllllllll}0 & 0 & 0 & 0 & 1 & 0 & 0 & 0 & 0 & 1 & 1 & 0 & 0 & 0 & 1 & 1 & 0 & 1 & 0 & 0 & 0 & 1 & 0 & 0 & 0 & 0\end{array}$ $\begin{array}{lllllllllllllllllllllllllll}0 & 1 & 1 & 1 & 1 & 0 & 0 & 0 & 1 & 0 & 1 & 0 & 1 & 1 & 0 & 0 & 0 & 0 & 0 & 0 & 0 & 0 & 0 & 0 & 1 & 0\end{array}$ $\begin{array}{llllllllllllllllllllllllll}0 & 0 & 0 & 0 & 1 & 0 & 0 & 0 & 1 & 1 & 1 & 1 & 0 & 1 & 1 & 1 & 0 & 0 & 0 & 0 & 1 & 1 & 0 & 1 & 0 & 1\end{array}$ $\begin{array}{llllllllllllllllllllllllll}0 & 1 & 1 & 1 & 1 & 0 & 0 & 1 & 1 & 1 & 0 & 0 & 1 & 1 & 0 & 0 & 0 & 0 & 0 & 0 & 0 & 0 & 0 & 1 & 0 & 0\end{array}$ $\begin{array}{lllllllllllllllllllllllllll}0 & 0 & 1 & 0 & 1 & 0 & 0 & 0 & 0 & 1 & 0 & 0 & 0 & 1 & 0 & 0 & 1 & 0 & 0 & 0 & 1 & 0 & 0 & 0 & 1 & 0\end{array}$ $\begin{array}{lllllllllllllllllllllllllll}0 & 0 & 0 & 1 & 1 & 0 & 0 & 0 & 1 & 1 & 0 & 1 & 1 & 1 & 0 & 1 & 0 & 0 & 0 & 1 & 0 & 1 & 0 & 1 & 1 & 0\end{array}$ $\begin{array}{llllllllllllllllllllllllll}0 & 0 & 1 & 0 & 1 & 1 & 1 & 0 & 0 & 0 & 1 & 1 & 0 & 0 & 0 & 1 & 1 & 1 & 0 & 0 & 1 & 0 & 0 & 1 & 0 & 1\end{array}$ $\begin{array}{lllllllllllllllllllllllllll}0 & 0 & 0 & 1 & 1 & 0 & 0 & 1 & 0 & 0 & 0 & 1 & 0 & 1 & 0 & 1 & 0 & 0 & 0 & 0 & 0 & 0 & 0 & 0 & 0 & 0\end{array}$ $\begin{array}{llllllllllllllllllllllllll}0 & 1 & 0 & 0 & 0 & 1 & 0 & 1 & 1 & 1 & 1 & 1 & 1 & 0 & 0 & 1 & 1 & 1 & 1 & 0 & 0 & 0 & 0 & 1 & 0 & 1\end{array}$ $\begin{array}{lllllllllllllllllllllllllll}0 & 1 & 0 & 0 & 0 & 0 & 1 & 0 & 0 & 1 & 0 & 0 & 1 & 0 & 1 & 1 & 0 & 1 & 1 & 0 & 0 & 0 & 0 & 1 & 1 & 0\end{array}$ $\begin{array}{llllllllllllllllllllllllll}0 & 0 & 1 & 0 & 1 & 0 & 1 & 1 & 0 & 1 & 1 & 0 & 1 & 0 & 0 & 1 & 0 & 1 & 0 & 0 & 0 & 0 & 0 & 1 & 0 & 0\end{array}$ $\begin{array}{lllllllllllllllllllllllllll}0 & 1 & 1 & 0 & 1 & 0 & 0 & 0 & 0 & 1 & 1 & 1 & 0 & 1 & 0 & 1 & 0 & 0 & 0 & 0 & 1 & 1 & 0 & 1 & 1 & 0\end{array}$
} 
TABLE 3 Countries with peace agreements (1989-2012) and the occurrence of PAM's provisions on each case $($ Yes $=1, N o=o)$

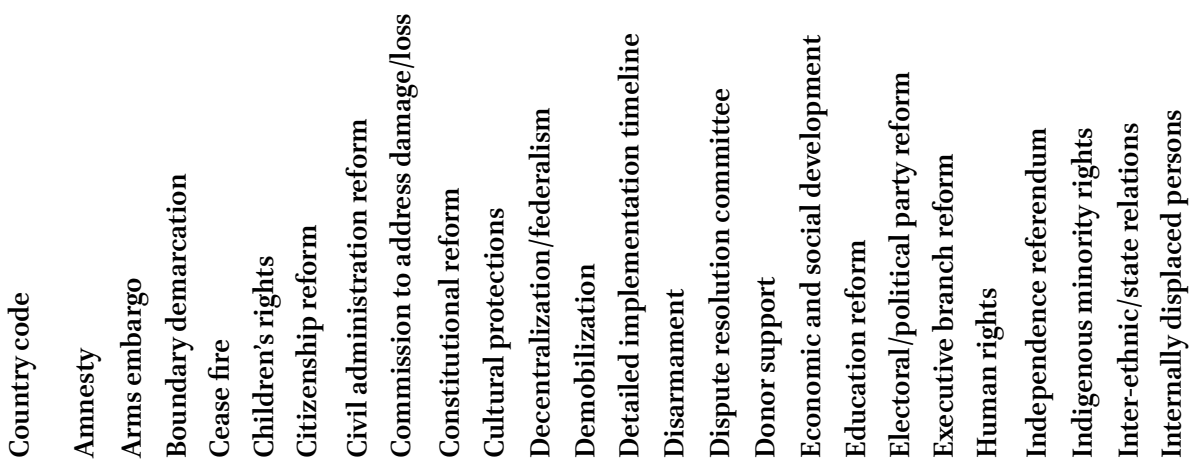

$\begin{array}{lllllllllllllllllllllllllll}\mathrm{C}_{2} 7 & 1 & 0 & 0 & 1 & 0 & 0 & 0 & 0 & 0 & 0 & 0 & 1 & 0 & 1 & 0 & 0 & 1 & 0 & 0 & 0 & 1 & 0 & 0 & 0 & 1 \\ \mathrm{C}_{2} 8 & 1 & 0 & 0 & 1 & 0 & 0 & 0 & 0 & 1 & 0 & 0 & 1 & 1 & 1 & 1 & 1 & 0 & 1 & 1 & 0 & 1 & 0 & 0 & 0 & 1 \\ \mathrm{C}_{29} & 1 & 0 & 0 & 1 & 1 & 1 & 0 & 0 & 1 & 1 & 1 & 1 & 0 & 0 & 1 & 0 & 1 & 1 & 1 & 1 & 1 & 0 & 0 & 0 & 0 \\ \mathrm{C}_{30} & 0 & 1 & 1 & 1 & 1 & 0 & 1 & 0 & 1 & 1 & 1 & 1 & 1 & 1 & 1 & 1 & 1 & 1 & 1 & 1 & 1 & 1 & 0 & 1 & 1 \\ \mathrm{C}_{31} & 1 & 0 & 0 & 1 & 0 & 0 & 0 & 0 & 1 & 0 & 0 & 1 & 0 & 1 & 1 & 1 & 0 & 0 & 1 & 1 & 0 & 0 & 0 & 0 & 1\end{array}$

SOURCE: PREPARED BY THE AUTHOR BASED ON DATA FROM THE KROC INSTITUTE FOR INTERNATIONAL PEACE STUDIES ${ }^{52}$

The first group of predictors (Appendix 3): "level of implementation," "amnesty," "arms embargo," "boundary demarcation," "ceasefire," "children's rights," "citizenship reform," "civil administration reform," "commission to address damage/loss," "constitutional reform," "cultural protections," "decentralization/ federalism," and "demobilization," when taken as a set, account for $70 \%$ of the variance in the contribution of personnel to UNMDPO $\left(\mathrm{R}^{2}=.70\right)$. The overall regression model was significant, $\alpha=.05, F(13,17)=3.06, p<.05$, meaning that there is only a $1.65 \%$ chance that the ANOvA output was obtained by chance.

One anticipated finding was that there is a significant possible correlation between the contribution to UNMDPO and the level of implementation of a peace agreement $(p=.016915<.05)$. In other words, the higher the level of implementation, the higher the possibility that a country would decide to contribute personnel to UNMDPO. Similarly, there is a significant possible correlation between the contribution to UNMDPO and the demobilization of an armed group as result of a peace agreement $(p=.044772<.05)$. 


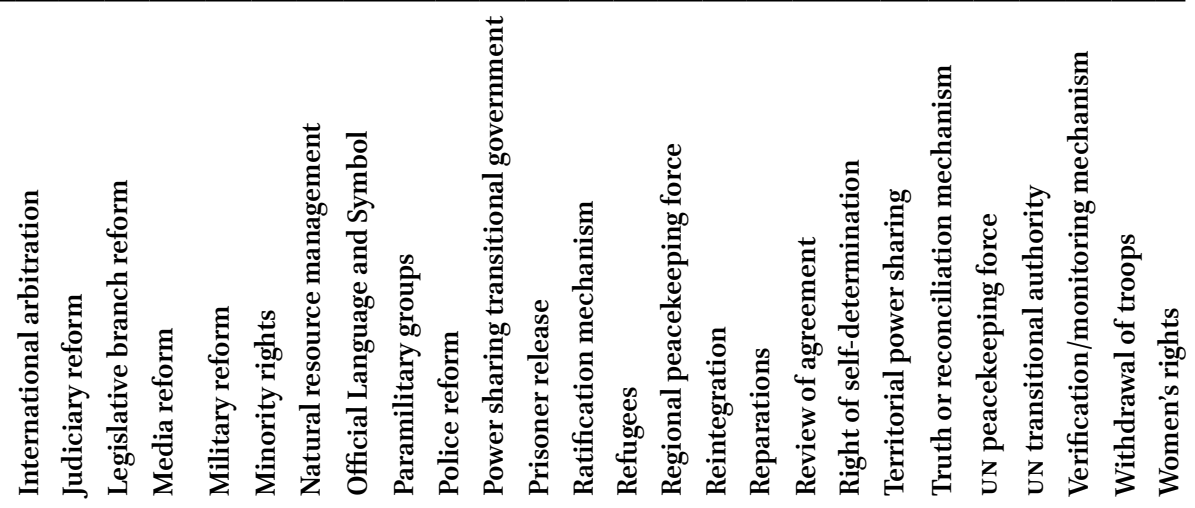

$\begin{array}{lllllllllllllllllllllllllll}0 & 0 & 0 & 0 & 0 & 0 & 0 & 0 & 0 & 0 & 0 & 0 & 0 & 1 & 0 & 1 & 0 & 0 & 0 & 0 & 0 & 0 & 0 & 0 & 0 & 0 \\ 0 & 0 & 0 & 0 & 1 & 0 & 1 & 0 & 1 & 0 & 1 & 1 & 0 & 1 & 1 & 1 & 1 & 1 & 0 & 0 & 1 & 1 & 0 & 1 & 0 & 1 \\ 0 & 1 & 1 & 0 & 1 & 0 & 0 & 1 & 0 & 1 & 1 & 1 & 1 & 0 & 0 & 1 & 0 & 0 & 0 & 0 & 1 & 0 & 0 & 1 & 0 & 0 \\ 0 & 0 & 1 & 1 & 1 & 1 & 1 & 1 & 1 & 1 & 1 & 1 & 1 & 1 & 0 & 1 & 0 & 1 & 1 & 1 & 1 & 1 & 0 & 1 & 1 & 1 \\ 0 & 1 & 0 & 1 & 1 & 0 & 0 & 0 & 1 & 1 & 1 & 1 & 0 & 1 & 1 & 1 & 0 & 0 & 0 & 0 & 0 & 0 & 0 & 1 & 0 & 0\end{array}$

In the case of Colombia, both the level of implementation of the peace agreement with the FARC and its demobilization are central when the country planned on contributing to UNMDPO. Nevertheless, it is important to consider that still there are other armed groups which may create the same level of violence as the FARC and, hence, full military capabilities would be needed in the country. To date, independent researchers, government officials, and the FARC itself have reported that several FARC factions will abandon the peace agreement to create a dissident group or join other groups. ${ }^{53}$ Likewise, transnational groups such as Mexico's Gulf Cartel have started to open new branches in Colombia to seize the vast criminal possibilities in the country, especially with

53 Julian Amorocho, 'La disidencia de las FARC, un fantasma que acecha el proceso de paz' http://www.elcolombiano.com/colombia/acuerdos-de-gobierno-y-farc/lo-que-usted -debe-saber-sobre-la-disidencia-de-las-farc-NE5745078 (accessed 15 August 2017); El Espectador, 'Defensoría alerta sobre reclutamiento forzado y extorsiones de bloque disidente de las FARC en Vaupés', http://www.elespectador.com/noticias/judicial/defensoria-alerta -sobre-reclutamiento-forzado-y-extorsi-articulo-664991 (accessed 15 August 2017); FARC, 'FARC-EP Separa a 5 Mandos de Sus Filas', http://www.eltiempo.com/contenido/politica/ proceso-de-paz/ARCHIVO/ARCHIVO-16772428-o.pdf. (accessed 17 August 2017). 
regards to smuggling, illegal migration, illicit mining, and drug trafficking. ${ }^{54} \mathrm{As}$ a result, traditional rural violence and crimes generated by the conflict with the FARC (such as homicides and massacres) have decreased, but urban crimes such as vehicle theft and common theft have increased. This is presumably due to the migration of the illegal organizations to the cities in which the most profitable crime opportunities exist (Figure 1).

In addition, the regression analysis showed that there is a significant possible correlation between the contribution of personnel to UNMDPO and citizenship reform as an outcome of a peace agreement $(p=0.044167<0.05)$; however, this may not be the case of Colombia as no process to define the acquiring or reacquiring of permanent residency or citizenship were debated by the FARC or the Colombian government nor included into the peace agreement.

The second group of predictors (Appendix 4), "detailed implementation timeline," "disarmament," "dispute resolution committee," "donor support," "economic and social development," "education reform," "electoral/political party reform," "executive branch reform," "human rights," "independence referendum," "indigenous minority rights," "inter-ethnic/state relations," and "internally displaced persons," when taken as a set, account for the $64 \%$ of the variance in the contribution of personnel to UNMDPO $\left(\mathrm{R}^{2}=.64\right)$. The overall regression model was non-significant, $\alpha=.05, F(13,17)=2.29, p>.05$, meaning that there is a $5.50 \%$ chance that the ANOVA output was obtained by chance. However, for the dummy variable "disarmament," $p=.042427<.05$, demonstrating that there is a significant possible correlation between the contribution of personnel to UNMDPO and the disarmament of an armed group as a result of a peace agreement. This correlation was expected because the fulfilment of disarmament, demobilization, and reintegration (DDR) of an armed group is perhaps the final goal of a peace agreement.

The third group of predictors (Appendix 5), "international arbitration," "judiciary reform," "legislative branch reform," "media reform," "military reform," "minority rights," "natural resource management," "official language and symbol," "paramilitary groups," "police reform," "power sharing transitional government," "prisoner release," and "ratification mechanism," when taken as a set, account for $62 \%$ of the variance in the contribution of personnel to UNMDPO $\left(\mathrm{R}^{2}=.62\right)$. The overall regression model was non-significant, $\alpha=.05$, $F(13,17)=2.16, p>.05$, meaning that there is a $6.88 \%$ chance that the ANOVA

54 Elida Moreno, 'Panama closes border with Colombia to stem migrant flow', http://www .reuters.com/article/us-panama-colombia-migrants-idUSKCNoYo21C (accessed 4 September 2017); Matthew Bristow, 'FARC play dominoes as drug cartels occupy Colombian 


\section{$-\diamond-$ Homicides $-\square-$ Vehicle theft $-\Delta^{--}$Common theft}
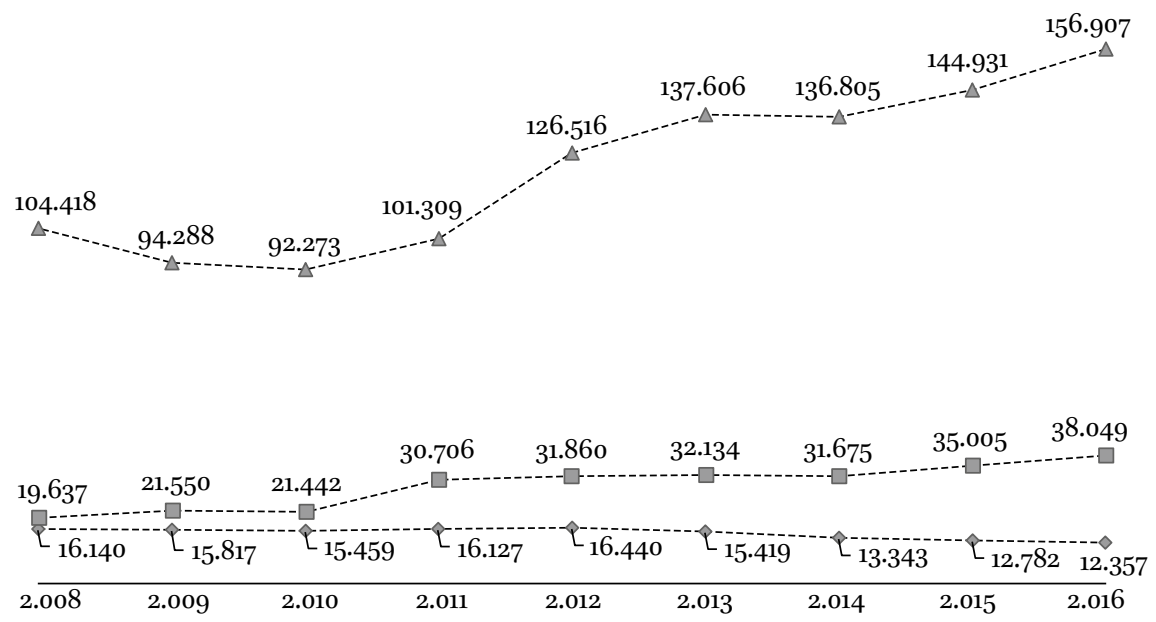

FIGURE 1 Variation of homicides, vehicle theft and common theft in Colombia (2008-2016). SOURCE: PREPARED BY THE AUTHOR BASED ON INFORMATION FROM THE COLOMBIAN MINISTRY OF DEFENSE55

output was obtained by chance. However, for the dummy variables "minority rights" $p=.017009<.05$ and "paramilitary groups" $p=.035393<.05$, demonstrating that there is a significant possible correlation between the contribution of personnel to UNMDPO and resolving issues with minorities and with paramilitary groups. Colombia has an unfortunate history of unresolved grievances on minority rights which many scholars identify as one of the motivators for the internal armed conflict. ${ }^{56}$ Similarly, criminal organizations misnamed as

villages', https://www.bloomberg.com/politics/articles/2017-02-08/farc-playing-dominoes -as-drug-cartels-occupy-colombian-villages (accessed 5 September 2017).

55 Colombian Ministry of Defense, Logros de la politica de defensa y seguridad todos por un nuevo pais', https://www.mindefensa.gov.co/irj/go/km/docs/Mindefensa/Documentos/ descargas/estudios_sectoriales/info_estadistica/Logros_Sector_Defensa.pdf (accessed 12 March 2017).

56 Eduardo Restrepo and Axel Rojas (eds.), 'Conflicto E (In)visibilidad: retos en los estudios de la gente negra en Colombia' (Popayan: Editorial Universidad del Cauca, 2004), http:// repository.oim.org.co/bitstream/20.500.11788/830/1/COL-OIM\%200o65.pdf; Hernan Trujillo, 'Realidades de la Amazonia colombiana: territorio, conflicto armado y riesgo socioecológico', Revista ABRA, vol. 34, no. 48, 2014, pp. 63-81, https://doi.org/10.15359/ abra.34-48.4; Cristian Tesillo, 'Importancia de la construcción de paz en un contexto de guerra: caso colombiano en el periodo 2000-2016', Revista Internacional de Cooperación y Desarrollo, vol. 3, no. 2, 2016, pp. 130-49, https://doi.org/10.21500/23825014.2782; 
paramilitary groups along with insurgent groups have been identified as instigators of a large part of the violence, dehumanization, and prolongation of the conflict. 57

The fourth group of predictors (Appendix 6), "refugees," "regional peacekeeping force," "reintegration," "reparations," "review of agreement," "right of self-determination," "territorial power sharing," "truth or reconciliation mechanism," "UN peacekeeping force," "UN transitional authority," "verification mechanism," "withdrawal of troops," and "women's rights," when taken as a set, account for $42 \%$ of the variance in the contribution of personnel to UNMDPO $\left(\mathrm{R}^{2}=.42\right)$. The overall regression model was non-significant, $\alpha=.05, F(13,17)=$ $.96, p>.05$, meaning that there is a $51.55 \%$ chance that the ANOvA output was obtained by chance. No dummy variables were statistically significant.

These results imply that conventional rationale in Colombia on the participation of countries arising from violent intra-state conflicts in UNMDPO as a common stage after the signing of a peace agreement is faulty as international experience shows that they usually consider several factors (such as the level of implementation of a peace agreement, the results of the DDR process, and resolving problems with citizenship, minority rights, and paramilitary groups) before making such a commitment. Therefore, Colombia should carefully assess the implications of participation in UNMDPO without having appropriately accomplished the provisions included in the peace agreement with the

Jose Tuiran, 'Emberá katío: un pueblo milenario que se niega a desaparecer tras un desplazamiento forzado que conlleva a su extinción física y cultural', Criterios, vol. 10, no. 1, 2017, pp. 79-110, https://doi.org/10.21500/20115733.3078; Germán Carvajal, Margarita Lopera, Martha Álvarez, Sandra Morales, José Herrera, 'Aproximaciones a la noción del Conflicto Armado en Colombia: una mirada histórica' Desbordes. Revista de Investigaciones. Escuela de Ciencias sociales, artes y humanidades - UNAD, vol. 6, no. 1, 2015, pp. 94-108, https://doi.org/10.22490/25394150.1870.

57 Jorge Giraldo, 'La Conflicto armado urbano y violencia homicida. El caso de Medellín', URVIO - Revista Latinoamericana de Estudios de Seguridad, vol. 1, no. 5, 2014, pp. 99-113, https://doi.org/10.17141/urvio.5.2008.1098; Francisco Gutierrez-Sanin, 'Propiedad, seguridad y despojo: el caso paramilitar' Revista Estudios Socio-Jurídicos, vol. 16, no. 1, 2014, pp. 43-74, http://www.redalyc.org/resumen.oa?id=733298100o2; Jenner Tobar, 'Violencia política y guerra sucia en colombia. memoria de una víctima del conflicto colombiano a propósito de las negociaciones de La Habana' Memoria y Sociedad, vol. 19, no. 38, 2015, pp. 9-22; Camilo Pacheco, 'Impacto económico de la violencia armada sobre la producción campesina, caso municipios zona de distensión departamento del Meta, Colombia (1991-2014)', Revista Lebret, vol. o, no. 8, 2016, pp. 93-123, https://doi.org/10.15332/rl.voi8 .1688; Jacobo Grajales, 'Gobernar en medio de la violencia: Estado y paramilitarismo en Colombia' (Bogota D.C.: Editorial Universidad del Rosario, 2017), https://doi.org/10.12804/ th 9789587387988 . 
FARC and the new grievances, threats, and challenges that the DDR of this rebel group may bring.

\section{The Complexity of Participating in UNMDPO}

A tendency in Colombia is the common impression that UNMDPO are important as an enhancer of foreign policy and legitimacy, ${ }^{58}$ showing a general unfamiliarity on the essence of the missions that would be assigned to the armed forces and the possible risks associated with them. Although this idea is not exclusive to Colombia several elements should be considered before considering the exportation of defense/security personnel as equivalent to traditional diplomacy. ${ }^{59}$ As suggested by Martinez and Duran, ${ }^{60}$ well-developed international missions may help to modernize the armed forces, change the mentality of the servicemen and women, and improve legitimacy, public opinion, and civil-military relations. However, involvement in an ill-chosen UNMDPO may signify negative results contrary to those sought both by the country and by the UN. The case of Rwanda in which the UN failed to stop the genocide between Tutsis and Hutus ${ }^{61}$ is a vivid example in which unaware and unprepared troops among a volatile scenario may curtail the scope of UNMDPO.

While UN military peacekeepers are essentially employed to "protect civilians and UN personnel; monitor a disputed border; monitor and observe peace processes in post-conflict areas; provide security across a conflict zone; assist in-country military personnel with training and support; and

$5^{8}$ José A. Sanahuja and Francisco J. Verdes-Montenegro, 'Seguridad y defensa en Suramérica: regionalismo, cooperación y autonomía en el marco de UNASUR', Anuario de integración UNASUR, no. 10, http://www.cries.org/wp-content/uploads/2014/11/19-Sanahuja -Montenegro.pdf; Tickner, 2016.

59 Benjamin Pohl, 'EU Foreign Policy and Crisis Management Operations: Power, Purpose and Domestic Politics', (London: Routledge, 2015); Monica Hirst and Reginaldo Nasser, Brazil's involvement in peacekeeping operations: the new defence-security foreign policy nexus, https://www.files.ethz.ch/isn/184486/1fo5a3ed4e305be65263bidd53fibd64.pdf (accessed 26 August 2017); Glenn Hastedt, 'American Foreign Policy: Past, Present, and Future', (Landham: Rowman \& Littlefield, 2014).

6o Rafael Martínez and Mariel Durán, 'International Missions as a Way to Improve CivilMilitary Relations: The Spanish Case (1989-2015)', Democracy and Security, vol. 13, no. 1, 2017, pp. 1-23, https://doi.org/10.1080/17419166.2016.123669o.

61 Romeo Dallaire and Samantha Power, 'Shake Hands with the Devil: The Failure of Humanity in Rwanda', (New York: Da Capo Press, 2004). 
assist ex-combatants in implementing the peace agreements, they may have signed", ${ }^{62}$ UN peacekeepers are usually dealing with unstable situations in which relapse into violence or a misunderstanding of their mission may cause fatalities. For example, until June 2017, 2,597 UN military peacekeepers, $88 \mathrm{UN}$ military observers, and $264 \mathrm{UN}$ police officers have died on mission. ${ }^{63}$ India reported 163 fatalities, Nigeria 150, Pakistan 142, Ghana 137, and Bangladesh 129, being these countries some of the most affected with fatalities during UNMDPO. ${ }^{64}$

Appendices 5 and 6 summarize the UNMDPO which have been developed so far, with an average per operation of 49 fatalities, 18 by accident, 16 by illness, 13 by malicious acts, and 3 by other non-disclosed reasons. While participation in UNMDPO may be a useful opportunity for Colombia to export its military capabilities, and expand its international recognition and prestige, the possibility of casualties occurring during such operations may be counterproductive to the collective imagination and the official vision of having one of the best militaries of the world, enhanced by the experience of almost 60 years of armed conflict. ${ }^{65}$ Exploring the best possible scenarios in which

62 United Nations Department of Peacekeeping Operations, 'Military - United Nations Peacekeeping', http://www.un.org/en/peacekeeping/issues/military/, (accessed 23 July 2017), [Thereafter United Nations Department of Peacekeeping Operations - Military, 2017].

63 United Nations Department of Peacekeeping Operations, 'Fatalities by Mission and Appointment Type', http://www.un.org/en/peacekeeping/fatalities/documents/stats_3jun .pdf, (accessed 23 July 2017).

64 United Nations Department of Peacekeeping Operations, 'Fatalities by Nationality and Mission', http://www.un.org/en/peacekeeping/fatalities/documents/stats_2jun.pdf., (accessed 23 July 2017).

65 Cesar Marino, "Fuerzas Armadas colombianas entrenan a sus pares de todo el mundo" Dialogo, 2015, https://dialogo-americas.com/es/articles/fuerzas-armadas-colombianas -entrenan-sus-pares-de-todo-el-mundo; Causil Rincon, ' $i$ Somos los mejores soldados del mundo!, http://www.esmic.edu.co/esmic/index.php/medios/actualidad/847-somos-los -mejores-soldados-del-mundo-subteniente-causil-rincon.html (accessed 9 September 2017); Semana, 'estos son los soldados de exportación', http://www.semana.com/nacion/ar ticulo/el-ejercito-colombiano-participaria-en-nuevas-misiones-internacionales/482058 (accessed 11 September 2017); Ricardo Monsalve, 'Otan quiere llevar soldados colombianos a Afganistán', http://www.elcolombiano.com/colombia/colombia-podria-tener-soldados -en-afganistan-IM5934028 (accessed 9 September 2017); Gr. Juan Pablo Amaya, 'Catedra Colombia: Inspeccion General Fuerzas Militares de Colombia', http://www,esdegue.mil .co/catedra_colombia1 (accessed 21 August 2017); Gr. Juan Pablo Rodriguez, 'Catedra Colombia: Comando General Fuerzas Militares de Colombia', http://www,esdegue.mil.co/ catedra_colombia4 (accessed 21 August 2017). 
the use of Colombian military, in the light of a comprehensive DotMLPFM-I assessment, ${ }^{66}$ should be a priority of the Colombian government when deciding to contribute troops to UNMDPO.

In the same way, UNMDPO have an average duration of eight years (Appendices 5 and 6). Such a duration may require at least three different contingents: one deployed in operations, one under training and certification to replace the contingent in operations, and a third being debriefed on its experiences and lessons learned during its deployment as well as providing advice on the improvement of policies and tactics in order to adequately fulfil the task and to meet the UN Peacekeeping Capability Readiness System (PCRS) and its four levels of readiness. ${ }^{67}$

Level 1: A Troop Contributing Country makes a formal pledge for a unit and provides the list of major and self-sustainment equipment and certification of completion of basic training and human rights screening. Member States are encouraged to include the time frame of availability and duration of deployment for each pledged capability.

Level 2: Based on the UN operational requirements, pledges at Level 1 can be elevated to Level 2 after an assessment and advisory visit has been conducted by a UN Headquarters team.

Level 3: Following a satisfactory assessment, units which have achieved a reasonable degree of preparedness are elevated to Level 3 .

Rapid Deployment Level (RDL): Having reached Level 3, the Troop Contributing Country may pledge to deploy within 60 days following a request made by the UN Headquarters.

Such quantity of troops and equipment may be required in-country to improve defense/security levels and to fight against FARC dissidences and other organized armed groups. Likewise, this situation may pose a risk to Colombia as engaging troops and equipment in such long missions may entail a heavy burden to in-country capabilities, especially because UNMDPO increasingly need not only infantry soldiers but also highly specialized troops and expensive

66 DOTMLPFM-I assessment stands for doctrine and policy, organization, training and education, material, leadership, personnel, facilities, maintenance and logistics, and interoperability. The objective of a DOTMLPFM-I assessment is to identify capability deficits in a military project, providing an estimation of the reliability of its scope and methods, through a functional mission and needs analysis', see: Andres E. Fernandez-Osorio, '2008 Russian Military Reform: An Adequate Response to Global Threats and Challenges of the Twenty-First Century?', Rev. Cient. Gen. Jose Maria Cordova, vol. 14, no. 17, 2016, p. 57.

67 United Nations Department of Peacekeeping Operations - Military, 2017. 
equipment (enablers such as engineers, helicopters and crews, transportation, communication experts, and medical personnel) ${ }^{68}$

Another common perception in Colombia is that countries emerging from armed conflicts by peace agreements no longer require the same military capabilities as they previously did and, hence, military defense expenditure should be decreased and the armed forces should redirect some of their experience to support international missions as a method of raising funds, encouraging self-sufficiency, and even contributing to the national economy. ${ }^{69} \mathrm{~A}$ regression analysis was undertaken to determine whether the contribution of personnel to UNMDPO is correlated with an increase/decrease in GDP and an increase/ decrease in military expenditure. Appendix 9 shows how these two predictors, when taken as a set, account for . $4 \%$ of the variance in the contribution of personnel to UNMDPO $\left(\mathrm{R}^{2}=.04\right)$. The overall regression model was nonsignificant, $\alpha=.05, F(2,28)=.54, p>.05$, meaning that there is a $59.10 \%$ chance that the ANOVA output was obtained by chance. These results imply that, based on international experience, both the variation in the national GDP and the variation in military expenditure are not correlated with the contribution of personnel to UNM DPO. Hence, stronger reasons should be considered when making a decision on participation in such operations. ${ }^{70}$ In fact, as explained by Mora-Tebas, ${ }^{71}$ although the UN reimburses contributing countries depending on the personnel and material provided to the mission, the values compensated are not significant and take time to be released.

Figure 2 depicts the variations in GDP and military expenditure of $3^{1}$ countries with peace agreements, from five years prior to the agreement to ten

68 United Nations Department of Peacekeeping Operations - Military, 2017.

69 Orlando Alarcon, 'Sostenibilidad de la economía de defensa colombiana con la participación en Operaciones de Paz', http://repository.unimilitar.edu.co/handle/10654/12888 (accessed 19 August 2017); Maria Ruiz, John Galeano, and Edwin Gil, 'Posconflicto colombiano y sus efectos económicos', Revista CIFE: Lecturas de Economía Social, vol. 17, no. 27, 2016, pp. 23-54. https://doi.org/10.15332/s0124-3551.2015.0027.01; Wilson Acosta, 'El post-conflicto y el gasto público: un desafío para Colombia', http://repository.unimilitar. edu.co/handle/10654/7809 (accessed 5 September 2017); Carlos Herran, 'Roles del sector Defensa Nacional en el posconflicto colombiano', http://repository.unimilitar.edu.co/ handle/10654/7144 (accessed 5 September 2017).

70 Fernando Chavarro Miranda, Manfred Grautoff Laverde and Julian Riaño Cruz, 'Model for Economic Growth and Public Spending Focused on Security: the Colombian Military Strategy Approach (2002-2009)', Rev. Cient. Gen. José María Córdova, vol. 15, no. 20, 2017, pp. 27-45. http://dx.doi.org/10.21830/19006586.174.

71 Juan Mora, 'Participacion en Operaciones [ONU] de Mantenimiento de la Paz [omps]: Motivacion de los Estados', Documento de Análisis IEEE, no. 63, http://www.ieee.es/ Galerias/fichero/docs_analisis/2016/DIEEEA63-2016_OMPs_Participacion_JAMT.pdf (accessed 13 September 2017). 
years thereafter. The figure shows how, during the years of conflict, significant proportions of the GDP are usually bound to the defense/security sector. This tendency is relatively maintained during the first three years following the signature of the peace agreement. However, from the fourth year, the GDP starts to increase, presumably due to a renewed stable and peaceful scenario. In turn, military expenditure starts to decrease.

Several countries have identified participation in UNMDPO as a heavy burden on their economies and the effectiveness of their international affairs, especially when the cooperation with supra-national organisms may signify a paradox between pursuing national interests and creating a regional security dilemma. ${ }^{72}$ On the one hand, countries may benefit from international cooperation and alliances to guarantee their national interests; but on the other hand, such defense/security agreements may endanger local coalitions which could react by maximizing military capabilities and limiting diplomatic mechanisms between nations. For example, the announcement of Colombia's signature of an agreement with the North Atlantic Treaty Organization (NATO) to share information and to cooperate to tackle common defense/security challenges provoked a military escalation by Venezuela and several criticisms from Ecuador, Nicaragua and Bolivia. ${ }^{73}$ Although, to date, no criticism has been aroused regarding the participation of Colombia in UNMDPO from countries in the

72 Susan R. Mills, 'The Financing of un Peacekeeping Operations: The Need for a Sound Financial Basis' in The United Nations and Peacekeeping, Issues in Peacekeeping and Peacemaking (London: Palgrave Macmillan, 1991), pp. 91-110, https://doi.org/10.1007/978-1-349 -20808-1_8; Ross Fetterly, 'The Cost of Peacekeeping: Canada', The Economics of Peace and Security Journal, vol. 1, no. 2, 2006, pp. 47-52, https://doi.org/10.15355/epsj.1.2.47; Nina Serafino, 'Peacekeeping and Related Stability Operations: Issues of u.s. Military Involvement', (Washington D.C: Congressional Research Service, 2007); Lisa Hultman, Jacob Kathman, and Megan Shannon, 'United Nations Peacekeeping and Civilian Protection in Civil War', American Journal of Political Science, vol. 57, no. 4, 2013, pp. 875-891, https://doi.org/10.1111/ ajps.12036; Lisa Hultman, Jacob Kathman, and Megan Shannon, 'Beyond Keeping Peace: United Nations Effectiveness in the Midst of Fighting', American Political Science Review, vol. 108, no. 4, 2014, pp. 737-753, https://doi.org/10.1017/Sooo3055414000446; Dejan Marolov and Strashko Stojanovski, 'The Balkan Wars through the Prism of the Wider Theoretical Framework of the Concept of the Security Dilemma', Balkan Social Science Review, no. 5, 2015, pp. 29-49.

73 Ed Adamczyk, 'Colombia to Start Talks with NATO, Angering Venezuela', https://www.upi .com/Top_News/World-News/2016/12/26/Colombia-to-start-talks-with-NATO-angering -Venezuela/4031482772513/ (accessed 23 July 2017); Gideon Long, 'Tensions Rise as Colombia Turns to Nato', https://www.thetimes.co.uk/article/tensions-rise-as-colombia-turns-to -nato-s7fmgsnmc (accessed 3 August 2017); TeleSur, 'Colombia to sign military cooperation dealwithNATo, VenezuelaOpposes'http://www.thedawn-news.org/2016/12/29/colombia-to -sign-military-cooperation-deal-with-nato-venezuela-opposes/ (accessed 12 August 2017). 


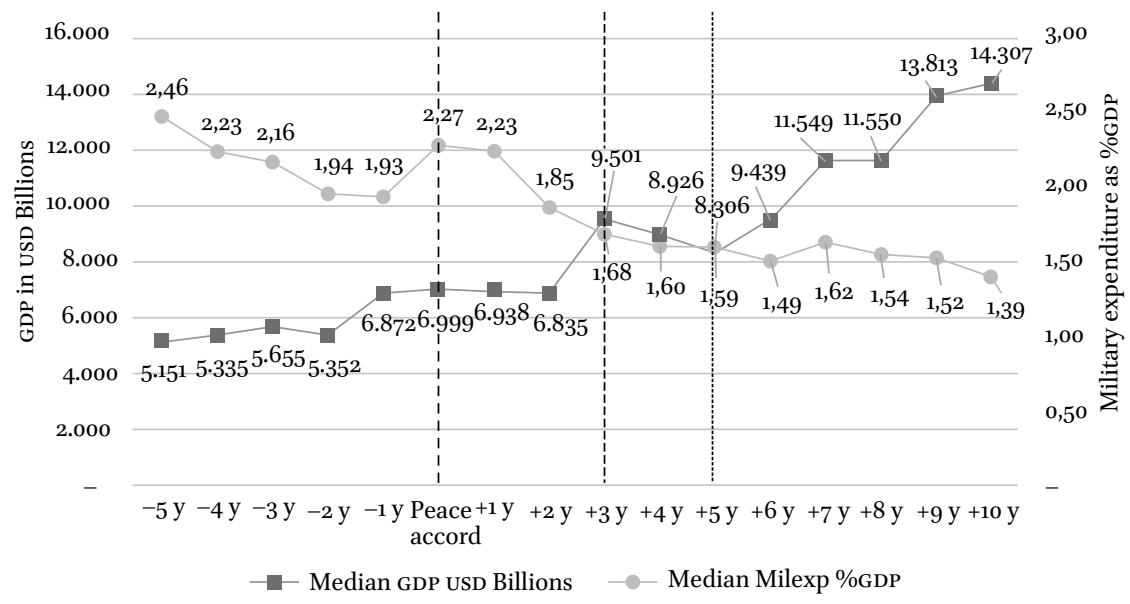

FIGURE 2 Variations in national GDP in billions of USD and military expenditure as \%GDP of 31 countries, from five years prior to a peace agreement until ten years thereafter (1989-2012).

SOURCE: PREPARED BY THE AUTHOR BASED ON INFORMATION FROM THE KROC INSTITUTE FOR INTERNATIONAL PEACE STUDIES, ${ }^{74}$ SIPRI, ${ }^{75}$ AND INTERNATIONAL MONETARY FUND ${ }^{76}$

Latin-American region. Possible complaints may surface if the actual unstable socio-economic and political circumstances of some countries deteriorate.

\section{Conclusion}

Colombia's success in its participation in UNMDPO may determine the future of highly trained and experienced military personnel from countries in which conflicts are being concluded and, hence, an option to export military capabilities to prevent of the relapse of violent conflict and the decline of possible new forms of aggression. However, cautious assessment before accepting such a demanding responsibility should be made to avoid erroneous conceptions which may lead to inadequate resolutions and strategies, converting such a decision into a national paradox between pursuing national interests or international recognition.

74 Peace Accord Matrix, 2017.

75 Stockholm International Peace Research Institute, 'SIPRI Military Expenditure Database', https://www.sipri.org/databases/milex, (accessed 4 April 2017) [Thereafter SIPRI, 2017].

76 International Monetary Fund, 'World Economic Outlook Database', https://www.imf.org, (accessed 4 April 2017) [Thereafter International Monetary Fund, 2017]. 
This article has shown how some of the reasons for participation in UNMDPO, widespread in Colombia, are inaccurate and disregard other significant elements by considering the international experience of 31 countries with characteristics similar to those of Colombia and which have emerged from violent intrastate conflicts. Firstly, the understanding of participation in UNMDPO as a tendency to follow is erroneous if it only considers the necessity of gaining international recognition or the improvement of foreign policy. The results of the regression analysis have shown how the level of implementation of the peace agreement with the FARC may be the best indicator for deciding when to start contributing peacekeepers and equipment to UNMDPO. Additionally, the fulfilment of DDR, resolving grievances with social and minority rights, and providing an adequate solution to the criminal groups issue is central to guarantee an exemplar contribution to peacekeeping.

Secondly, conventional wisdom in Colombia usually disregards the scope of UNMDPO and their associated risks. For example, the average duration of such operations and the average fatalities associated therewith are rarely mentioned. Neither is the impact of possible UNMDPO ill-assessed missions on the prestige of the Colombian armed forces. A thoughtful DotmLPFM-I assessment should be completed considering the possible operations, their environments, and their relevant cultural elements. Likewise, while UNMDPO may improve legitimacy and prestige, it poses a dilemma when alliances with organisms such as the UN signify a choice between pursuing international interests and producing a local security dilemma with countries which do not agree with international coalitions outside of the relevant region.

Thirdly, the idea of using UNMDPO as a source of funding for both the Colombian armed forces and the government is imprecise and contradictory as international experience has shown that participation in UNMDPO requires an adequate budget to sustain contingents and equipment. UN reimbursement is fair and takes time to be released. Likewise, countries emerging from violent conflicts tend to reduce defense budgets as their GDP increases, showing a tendency to funnel some parts of military expenditure to other areas.

This article has raised many questions on this under-researched topic in Colombia. It does not pretend to cover every possible aspect within the discussion. On the contrary, it has aimed to make an initial approach to the theme, highlighting the necessity of further research before making final decisions. Besides, this article provides the Colombian government and the armed forces with an academic framework to advance in at least three areas: to identify the strategies and interactions between actors in UNMDPO, to analyze the institutional changes required in the defense/security sector needed to participate in UNMDPO, and to improve the decision-making process to assess possible missions in which to participate in light of the capabilities and experience of the armed forces. 


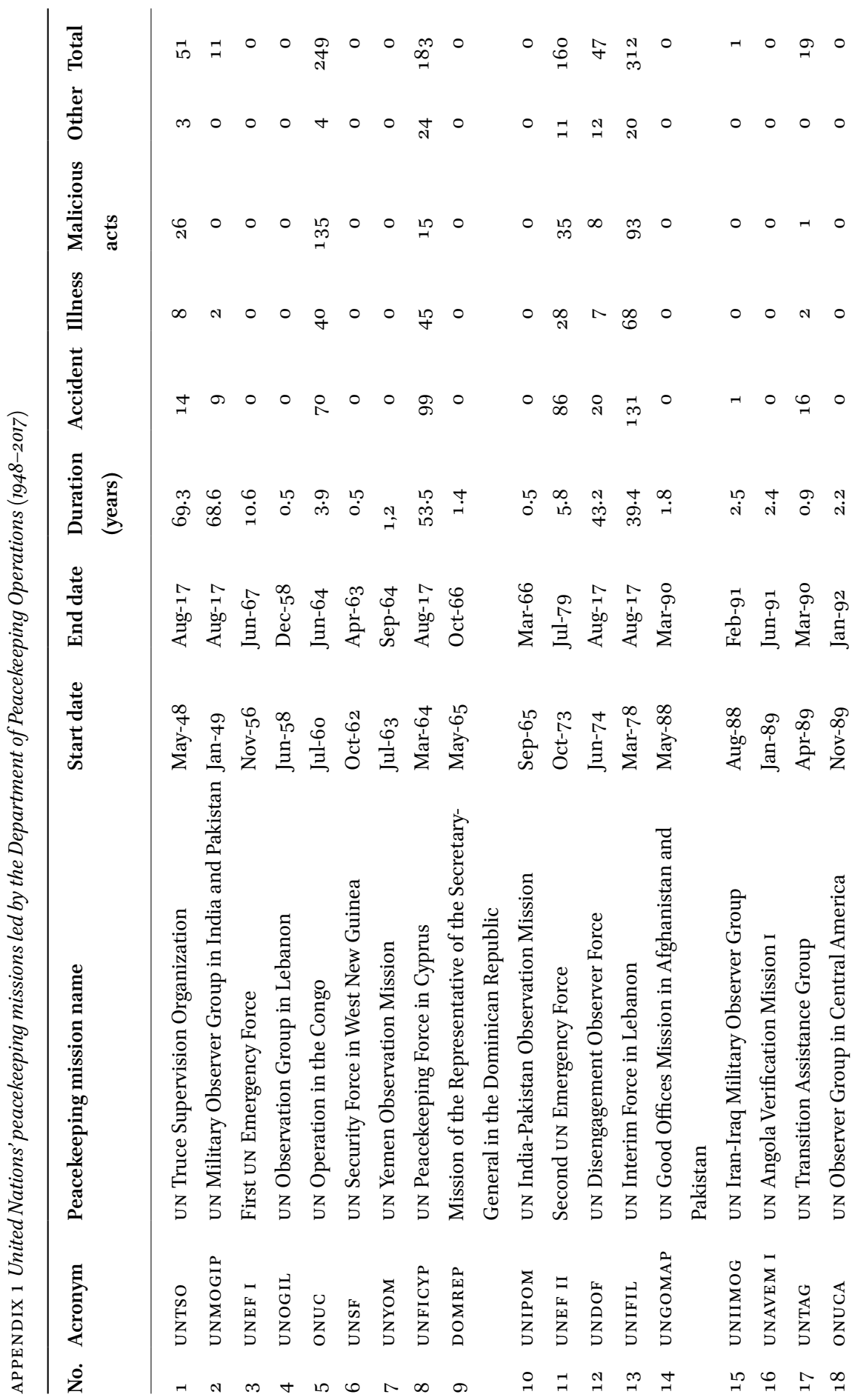




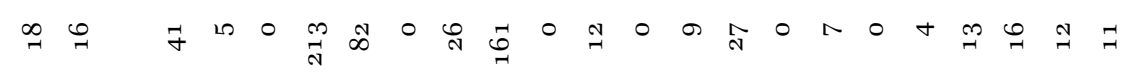

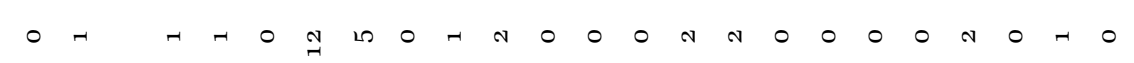

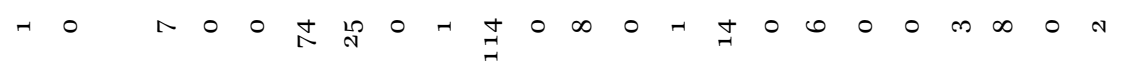

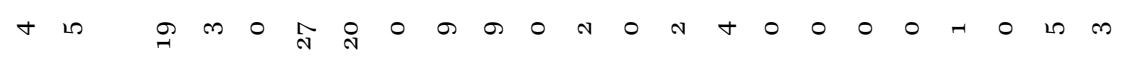

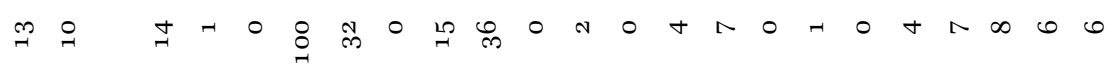

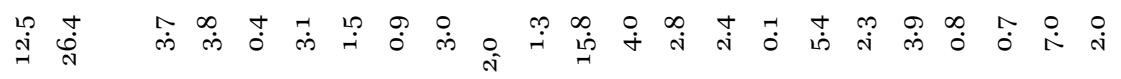

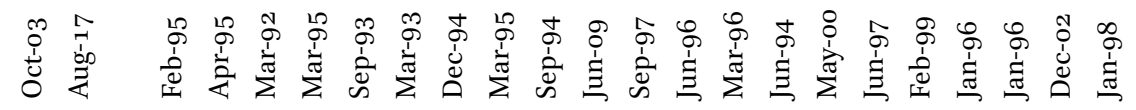

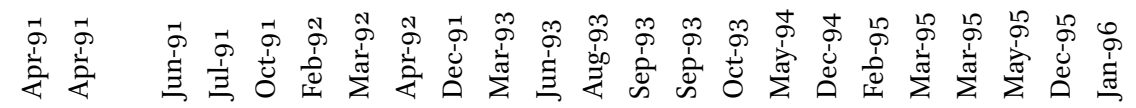

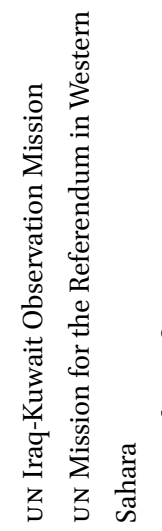

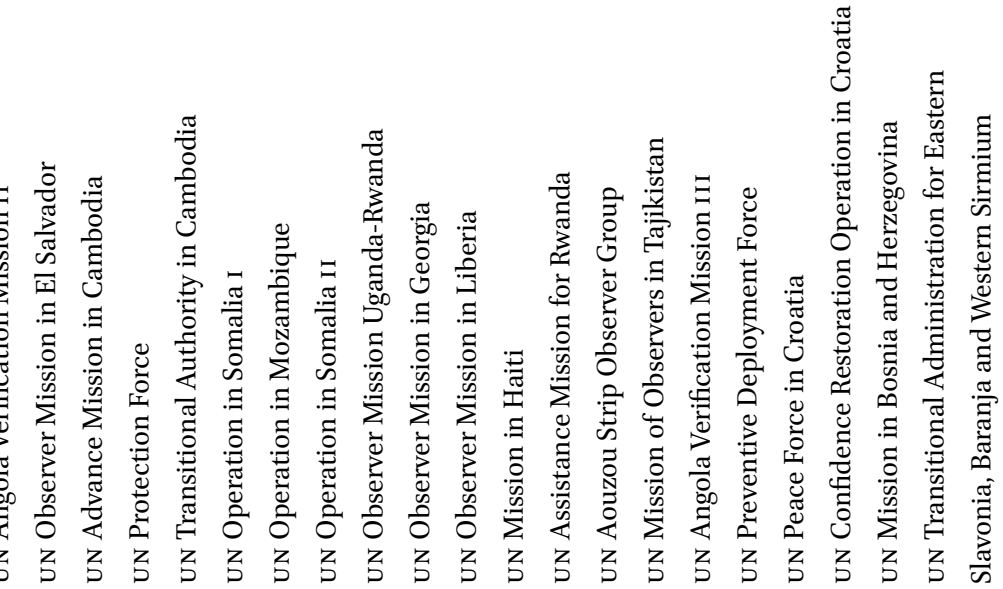

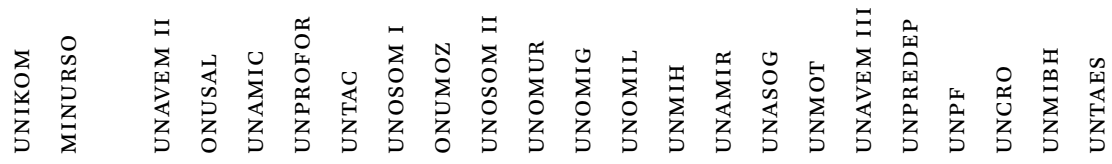

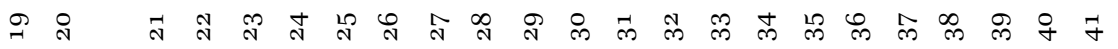




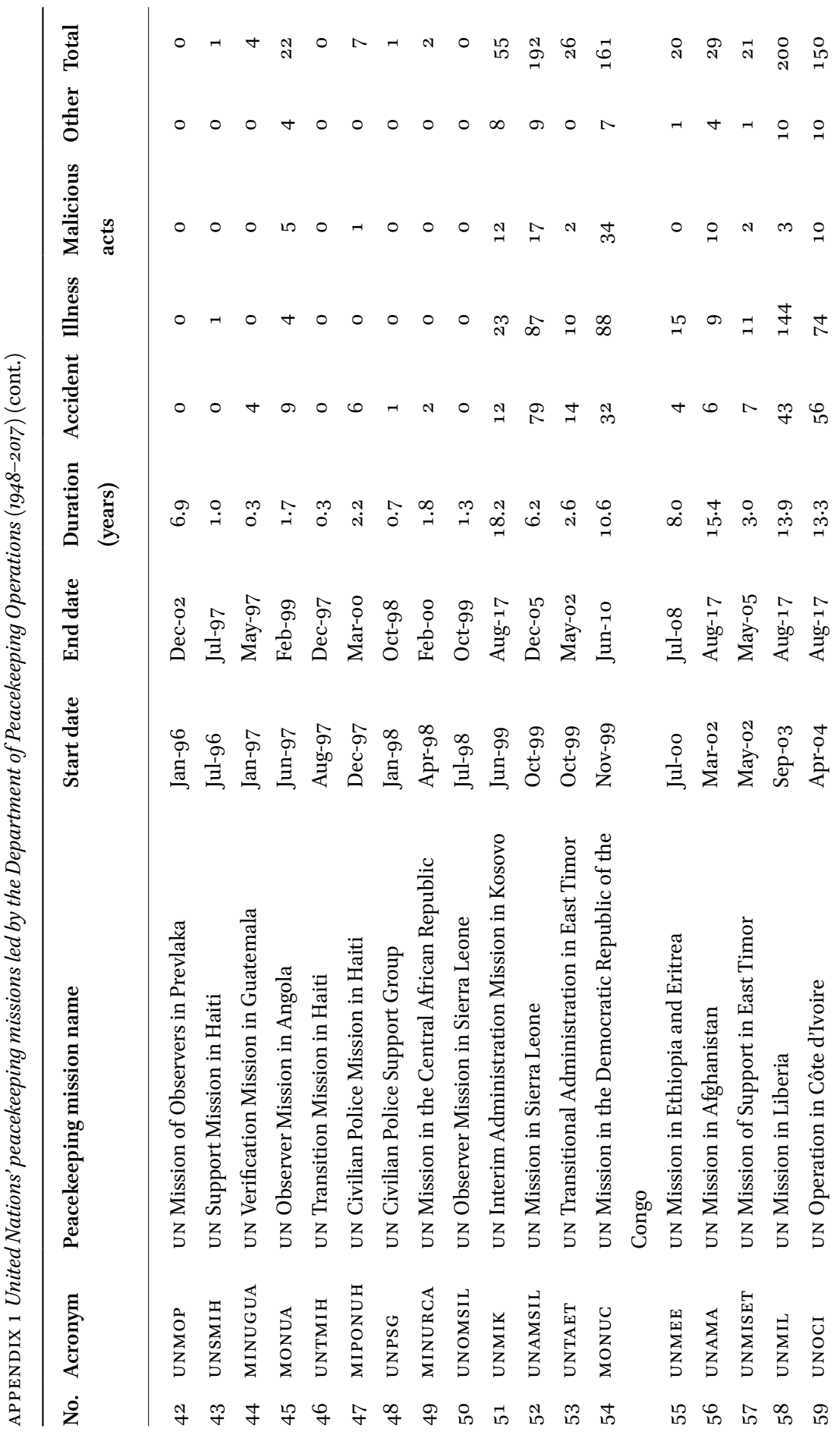




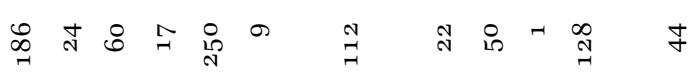

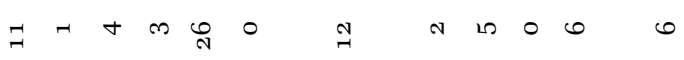

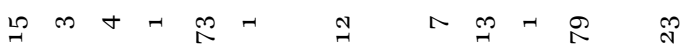

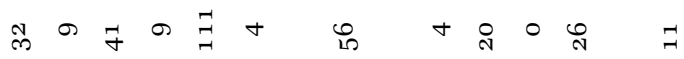

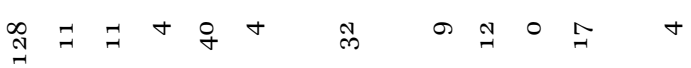

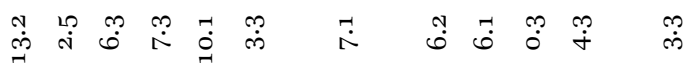

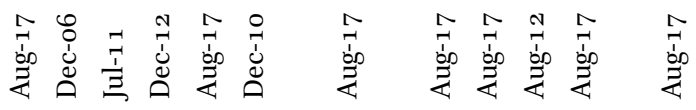

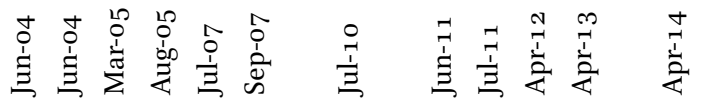

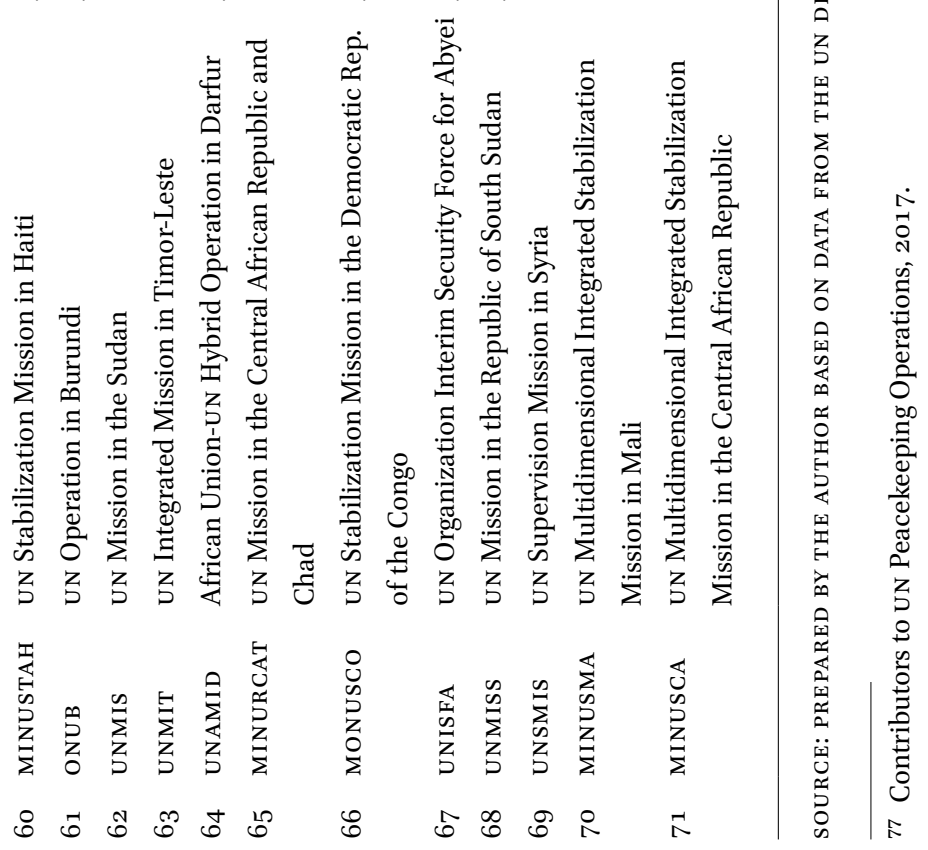




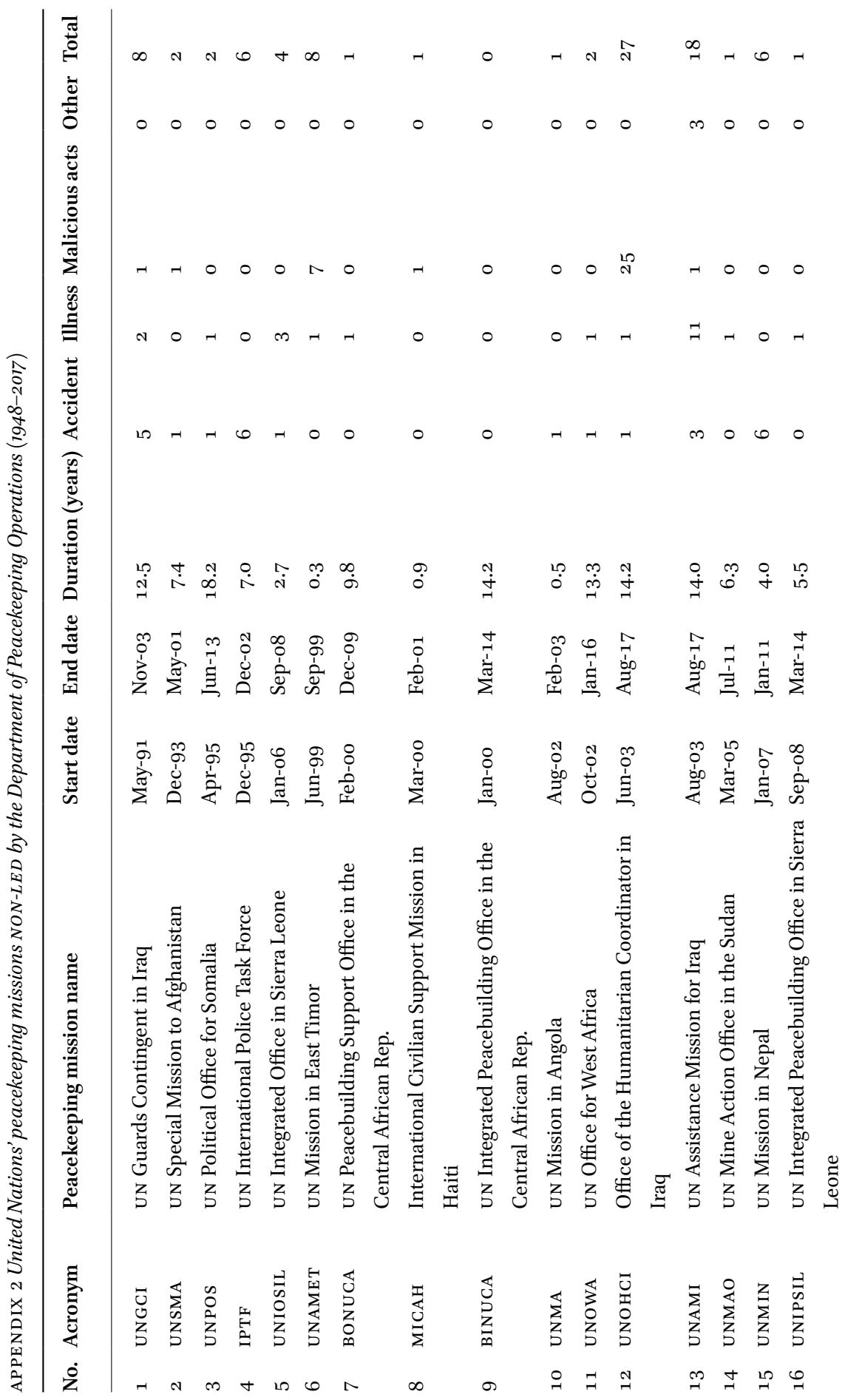




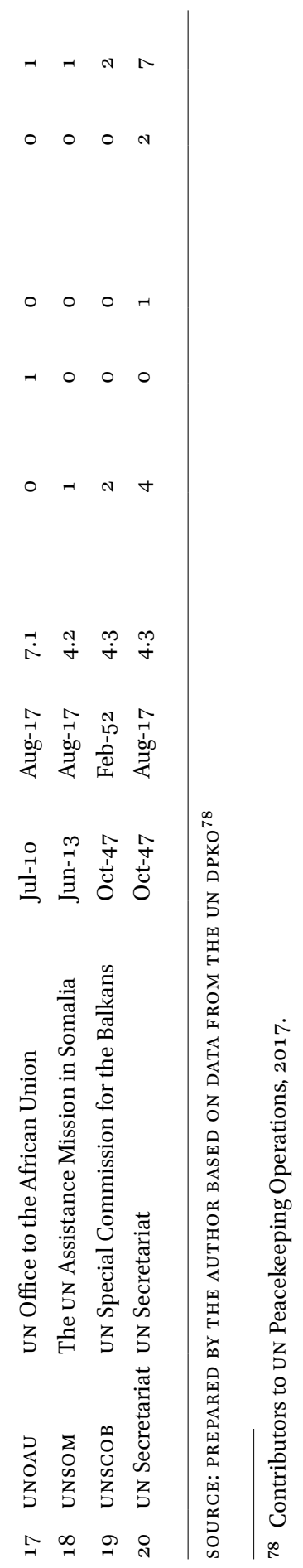


APPENDIX 3 Summary output - first group of predictors on the variance of contribution of personnel to UNMDPO

Regression Statistics

Multiple R

0.84

R Square

0.70

Adjusted R Square

0.47

Standard Error

1610.06

Observations

ANOVA

Regression

Residual

Total

$d f$

ss

MS

$F$ Significance $F$

$13 \quad 103038674.78 \quad 7926051.91$

3.06

0.016522

$17 \quad 44069029.99 \quad 2592295.88$

$30 \quad 147107704.77$

\begin{tabular}{lrrrrr} 
& Coefficients & Standard Error & t Stat & P-value & Lower 95\% \\
Intercept & 5829.49 & 1965.51 & 2.97 & 0.008662 & 1682.63 \\
Implementation (o-100\%) & -70.49 & 26.62 & -2.65 & 0.016915 & -126.65 \\
Amnesty (Y-N) & -667.63 & 686.31 & -0.97 & 0.344300 & -2115.61 \\
Arms embargo (Y-N) & -2061.30 & 1187.04 & -1.74 & 0.100559 & -4565.73 \\
Boundary demarcation & 1928.31 & 1331.50 & 1.45 & 0.165749 & -880.92 \\
(Y-N) & & & & & \\
Cease fire (Y-N) & -743.85 & 1097.68 & -0.68 & 0.507110 & -3059.76 \\
Children's rights (Y-N) & 662.68 & 948.30 & 0.70 & 0.494117 & -1338.04 \\
Citizenship reform (Y-N) & 1675.95 & 771.10 & 2.17 & 0.044167 & 49.08 \\
Civil administration reform & -619.40 & 682.81 & -0.91 & 0.377018 & -2060.01 \\
(Y-N) & & & & & \\
Commission to address & -380.97 & 2405.97 & -0.16 & 0.876052 & -5457.11 \\
damage/loss (Y-N) & & & & & \\
Constitutional reform (Y-N) & -92.01 & 904.43 & -0.10 & 0.920159 & -2000.18 \\
Cultural protections (Y-N) & -1378.54 & 961.46 & -1.43 & 0.169765 & -3407.04 \\
Decentralization/federalism & 230.12 & 826.98 & 0.28 & 0.784163 & -1514.65 \\
(Y-N) & & & & & \\
Demobilization (Y-N) & 2354.34 & 1086.70 & 2.17 & 0.044772 & 61.61 \\
\hline & & & & & \\
\hline & & & & &
\end{tabular}


APPENDIX 4 Summary output - second group of predictors on the variance of contribution of personnel to UNMDPO

\section{Regression Statistics}

Multiple R

R Square

Adjusted R Square

Standard Error

Observations

ANOVA

Regression

Residual

Total
0.80

0.64

0.36

1772.37

31

\begin{tabular}{|c|c|c|c|c|c|}
\hline & Coefficients & Standard Error & tStat & P-value & Lower 95\% \\
\hline Intercept & -143.22 & 1389.93 & -0.10 & 0.919137 & $-3075 \cdot 71$ \\
\hline $\begin{array}{l}\text { Detailed implementation } \\
\text { timeline }(\mathrm{Y}-\mathrm{N})\end{array}$ & -122.11 & 916.60 & -0.13 & $0.8955^{8} 3$ & -2055.96 \\
\hline Disarmament $(\mathrm{Y}-\mathrm{N})$ & 2835.09 & 1292.24 & 2.19 & 0.042427 & 108.71 \\
\hline $\begin{array}{l}\text { Dispute resolution } \\
\text { committee }(\mathrm{Y}-\mathrm{N})\end{array}$ & $-943 \cdot 5^{2}$ & 1002.92 & -0.94 & 0.359999 & $-3059 \cdot 5^{1}$ \\
\hline Donor support (Y-N) & -1792.18 & 884.08 & -2.03 & 0.058622 & -3657.42 \\
\hline $\begin{array}{l}\text { Economic and social } \\
\text { development (Y-N) }\end{array}$ & 1780.14 & $857 \cdot 94$ & 2.07 & 0.053490 & -29.95 \\
\hline Education reform (Y-N) & -539.60 & 804.02 & -0.67 & 0.511157 & -2235.93 \\
\hline $\begin{array}{l}\text { Electoral/political party } \\
\text { reform }(\mathrm{Y}-\mathrm{N})\end{array}$ & -109.66 & 1062.76 & -0.10 & 0.919026 & -2351.89 \\
\hline $\begin{array}{l}\text { Executive branch reform } \\
(\mathrm{Y}-\mathrm{N})\end{array}$ & 1374.27 & 1006.54 & 1.37 & 0.189941 & $-749 \cdot 34$ \\
\hline Human rights (Y-N) & $-45^{1.31}$ & 923.83 & -0.49 & 0.631425 & -2400.43 \\
\hline $\begin{array}{l}\text { Independence } \\
\text { referendum (Y-N) }\end{array}$ & -1545.20 & 1246.45 & -1.24 & 0.231933 & -4174.98 \\
\hline $\begin{array}{l}\text { Indigenous minority } \\
\text { rights }(\mathrm{Y}-\mathrm{N})\end{array}$ & 2001.01 & $1257 \cdot 32$ & 1.59 & 0.129921 & -651.69 \\
\hline $\begin{array}{l}\text { Inter-ethnic/state } \\
\text { relations }(\mathrm{Y}-\mathrm{N})\end{array}$ & 168.42 & 1129.68 & 0.15 & 0.883243 & -2215.01 \\
\hline $\begin{array}{l}\text { Internally displaced } \\
\text { persons (Y-N) }\end{array}$ & -849.84 & 1034.00 & -0.82 & 0.422516 & -3031.38 \\
\hline
\end{tabular}


APPENDIX 5 Summary output - third group of predictors on the variance of contribution of personnel to UNMDPO

Regression Statistics

Multiple R

R Square

Adjusted R Square

Standard Error

Observations

ANOVA

Regression

Residual

Total

Intercept

International arbitration (Y-N)

Judiciary reform (Y-N)

Legislative branch reform $(\mathrm{Y}-\mathrm{N})$

Media reform (Y-N)

Military reform (Y-N)

Minority rights (Y-N)

Natural resource management $(\mathrm{Y}-\mathrm{N})$

Official Language and Symbol (Y-N)

Paramilitary groups (Y-N)

Police reform (Y-N)

Power sharing transitional

government (Y-N)

Prisoner release (Y-N)

Ratification mechanism (Y-N)
0.79

0.62

0.33

1806.35

31

df $\quad$ ss $\quad M S \quad F$ Significance $F$

$\begin{array}{lllll}13 & 91638629.80 & 7049125.37 & 2.16 & 0.068861\end{array}$

$\begin{array}{llll}17 & 55469074.97 & 3262886.76\end{array}$

$30 \quad 147107704.77$

$\begin{array}{rrrrr}\text { Coefficients } & \text { Standard Error } & t \text { Stat } & \text { P-value } & \text { Lower 95\% } \\ 1437.52 & 928.36 & 1.55 & 0.139928 & -521.15 \\ -1103.65 & 2547.74 & -0.43 & 0.670325 & -6478.91 \\ 1267.82 & 750.92 & 1.69 & 0.109599 & -316.47 \\ 1124.59 & 945.00 & 1.19 & 0.250384 & -869.19 \\ -288.88 & 965.14 & -0.30 & 0.768330 & -2325.14 \\ 6.18 & 1050.41 & 0.01 & 0.995372 & -2210.00 \\ 2751.95 & 1040.35 & 2.65 & 0.017009 & 557.01 \\ -902.26 & 798.90 & -1.13 & 0.274427 & -2587.80 \\ -421.09 & 916.70 & -0.46 & 0.651803 & -2355.16 \\ -2127.91 & 931.03 & -2.29 & 0.035393 & -4092.21 \\ 121.20 & 804.28 & 0.15 & 0.881987 & -1575.68 \\ -805.78 & 823.82 & -0.98 & 0.341738 & -2543.90 \\ 1519.23 & 773.12 & 1.97 & 0.065963 & -111.90 \\ -1687.94 & 943.72 & -1.79 & 0.091512 & -3679.01\end{array}$


APPENDIX 6 Summary output-fourth group of predictors on the variance of contribution of personnel to UNMDPO

\section{Regression Statistics}

Multiple R

R Square

Adjusted R Square

Standard Error

Observations

ANOVA

\section{Regression}

Residual

Total

\section{Intercept \\ Refugees (Y-N)}

Regional peacekeeping force (Y-N)

Reintegration (Y-N)

Reparations (Y-N)

Review of agreement (Y-N)

Right of self-determination (Y-N)

Territorial power sharing $(\mathrm{Y}-\mathrm{N})$

Truth or reconciliation mechanism (Y-N)

UN peacekeeping force (Y-N)

UN transitional authority (Y-N)

Verification/monitoring mechanism (Y-N)

Withdrawal of troops (Y-N)

Women's rights (Y-N)

$$
\begin{array}{r}
0.65 \\
0.42 \\
-0.02
\end{array}
$$

\begin{tabular}{|c|c|c|c|c|}
\hline Coefficients & Standard Error & $t$ Stat & P-value & Lower 95\% \\
\hline$-14 \cdot 30$ & 1817.10 & -0.01 & 0.993814 & -3848.05 \\
\hline-372.01 & 1201.84 & -0.31 & 0.760678 & -2907.67 \\
\hline-2260.94 & 1383.48 & -1.63 & 0.120588 & -5179.82 \\
\hline 1882.41 & 1180.91 & 1.59 & 0.129349 & -609.09 \\
\hline $1864.5^{6}$ & 1433.12 & 1.30 & 0.210602 & -1159.07 \\
\hline-708.42 & $1253 \cdot 33$ & -0.57 & 0.579301 & $-335^{2.71}$ \\
\hline-511.08 & 1759.48 & -0.29 & 0.774967 & -4223.26 \\
\hline$-3479 \cdot 5^{1}$ & 2404.28 & -1.45 & 0.166025 & $-855^{2.09}$ \\
\hline$-597 \cdot 73$ & 1230.93 & -0.49 & o.633455 & $-3194 \cdot 76$ \\
\hline 2022.57 & $175^{8.89}$ & 1.15 & 0.266100 & -1688.37 \\
\hline-3011.43 & $2679 \cdot 38$ & -1.12 & 0.276664 & -8664.42 \\
\hline 271.57 & 1176.40 & 0.23 & 0.820191 & -2210.42 \\
\hline 1204.23 & 1035.77 & 1.16 & 0.261034 & -981.04 \\
\hline-801.25 & 1737.55 & -0.46 & 0.650545 & $-4467 \cdot 16$ \\
\hline
\end{tabular}

2231.41

31

SOURCE: PREPARED BY THE AUTHOR, VALUES WITH $P$-VALUE < .05 ARE Highlighted 


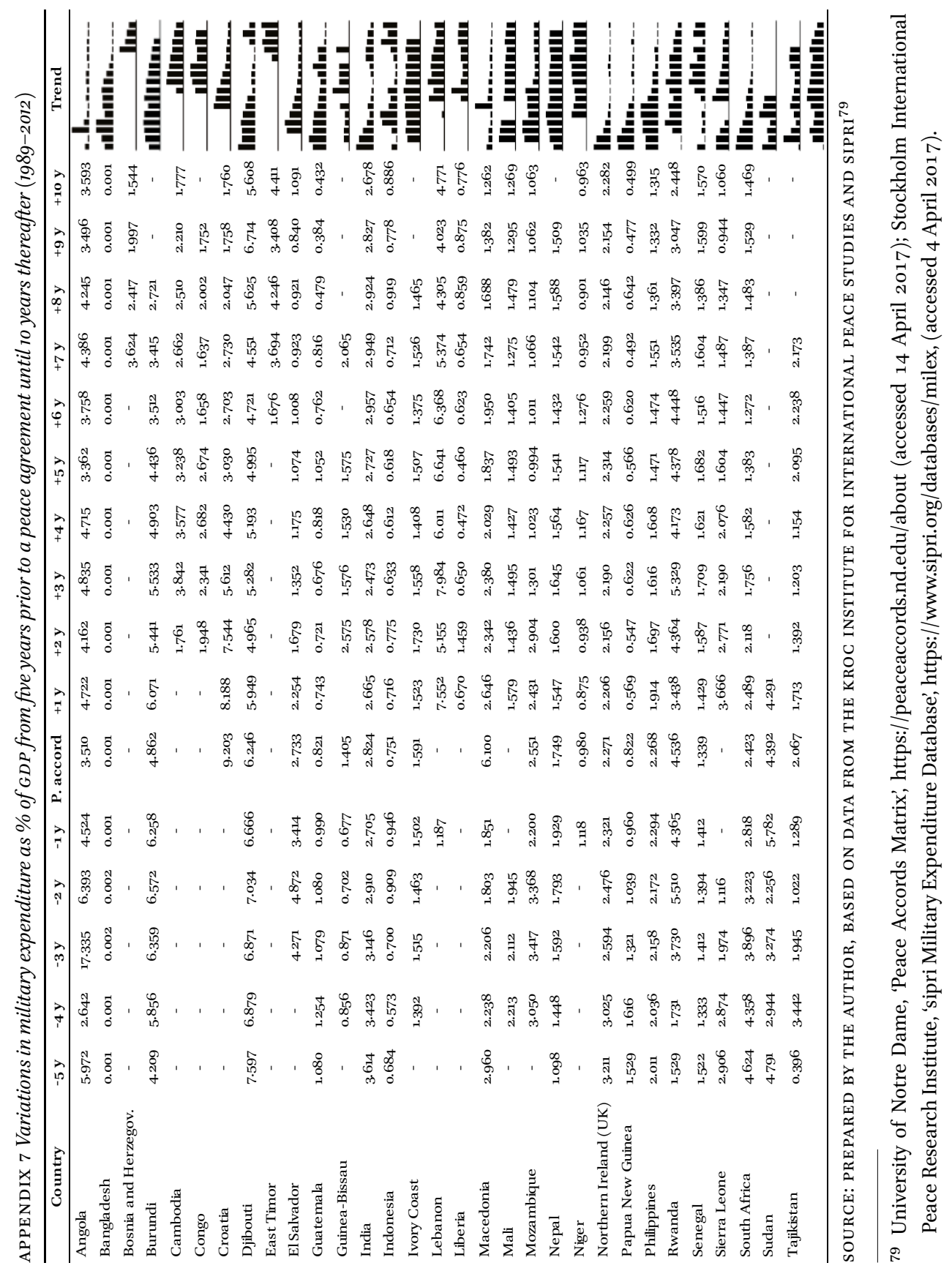




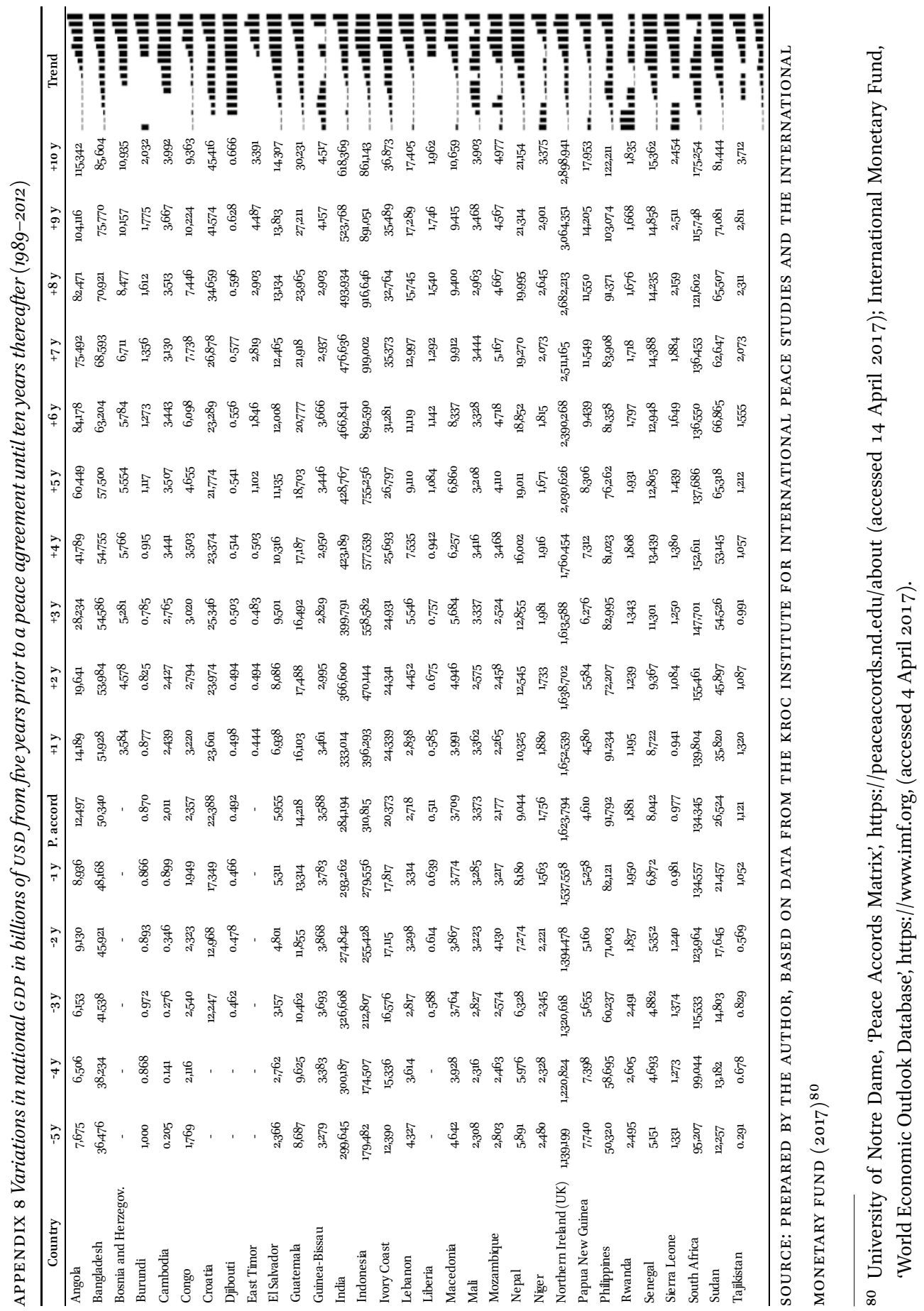


APPENDIX 9 Summary output - influence of GDP and Mil. Exp. on the variance of contribution of personnel to UNMDPO

Regression Statistics

Multiple R

$$
\begin{array}{r}
0.19 \\
0.04 \\
-0.03 \\
249.48 \\
31
\end{array}
$$

R Square

Adjusted R Square

Standard Error 2249.48

Observations

ANOVA

Regression

$$
d f
$$

ss

MS

F Significance $F$

Residual

$2 \quad 5422615.03 \quad 2711307.5^{2}$

0.54

0.591074

Total

$28 \quad 141685089.74 \quad 5060181.78$

$30 \quad 147107704.77$

$\begin{array}{lrrrrr} & \text { Coefficients } & \text { Standard Error } & t \text { Stat } & P \text {-value } & \text { Lower 95\% } \\ \text { Intercept } & 1755.01 & 786.72 & 2.23 & 0.033885 & 143.48 \\ \text { GDP } & 0.00 & 0.00 & 0.50 & 0.620513 & 0.00 \\ \text { Milex \%GDP } & -237.60 & 270.62 & -0.88 & 0.387413 & -791.94\end{array}$

SOURCE: PREPARED BY THE AUTHOR, VALUES WITH $P$-VALUE $<.05$ ARE HIGHLIGHTED 